\title{
Pesticide and veterinary drug residues in Belgian beeswax: Occurrence, toxicity, and risk to honey bees
}

\author{
Noëmie El Agrebi ${ }^{a}$, Kirsten Traynor ${ }^{b}$, Olivier Wilmart ${ }^{c}$, Simone Tosi ${ }^{d}$, Laurent Leinartz ${ }^{e}$, Ellen Danneels ${ }^{f}$, \\ Dirk C. de Graaf ${ }^{\text {f,g }}$, Claude Saegerman ${ }^{\mathrm{a}, *}$
}

a Research Unit of Epidemiology and Risk Analysis Applied to Veterinary Sciences (UREAR-ULiège), Fundamental and Applied Research for Animal and Health (FARAH) Center, Faculty of Veterinary Medicine, University of Liège, Quartier Vallée 2, Avenue de Cureghem 7A, B42, 4000 Liège, Sart-Tilman, Belgium

${ }^{\mathrm{b}}$ Global Biosocial Complexity Initiative, Arizona State University, Tempe, AZ, USA

' Federal Agency for the Safety of the Food Chain (FASFC), Directorate Control Policy, Staff Direction for Risk Assessment, Boulevard du Jardin Botanique 55, 1000 Brussels, Belgium

${ }^{d}$ Epidemiology Unit, University Paris Est, ANSES (French Agency for Food, Environmental and Occupational Health and Safety) Animal Health Laboratory, Maisons-Alfort, France

e Teaching Support Unit, Faculty of Veterinary Medicine, University of Liège, Quartier Vallée 2, Avenue de Cureghem 5C-5D, B41, 4000 Liège, Sart-Tilman, Belgium

${ }^{\mathrm{f}}$ Faculty of Sciences, Honeybee Valley, Ghent University (UGent), Krijgslaan 281 S33, 9000 Ghent, Belgium

${ }^{\mathrm{g}}$ Faculty of Sciences, Laboratory of Molecular Entomology and Bee Pathology, Ghent University (UGent), Krijgslaan 281 S2, 9000 Ghent, Belgium

\section{H I G H L I G H T S}

- Pesticide levels in brood comb, recycled comb, honey comb, and cappings wax were compared.

- 54 different pesticide and veterinary drug residues were found in the four types of beeswax.

- In-hive applied or high lipophilic residues are more likely to be found in beeswax.

- A statistically significant influence of chlorfenvinphos on bee mortality was found.

- Cappings wax was substantially less contaminated.

\section{A R T I C L E I N F O}

\section{Article history:}

Received 4 April 2020

Received in revised form 28 June 2020

Accepted 15 July 2020

Available online 22 July 2020

Editor: Yolanda Picó

\section{Keywords:}

Apis mellifera

Beeswax

Pesticide

Residues

Veterinary drug
G R A P H I C A L A B S T R A C T

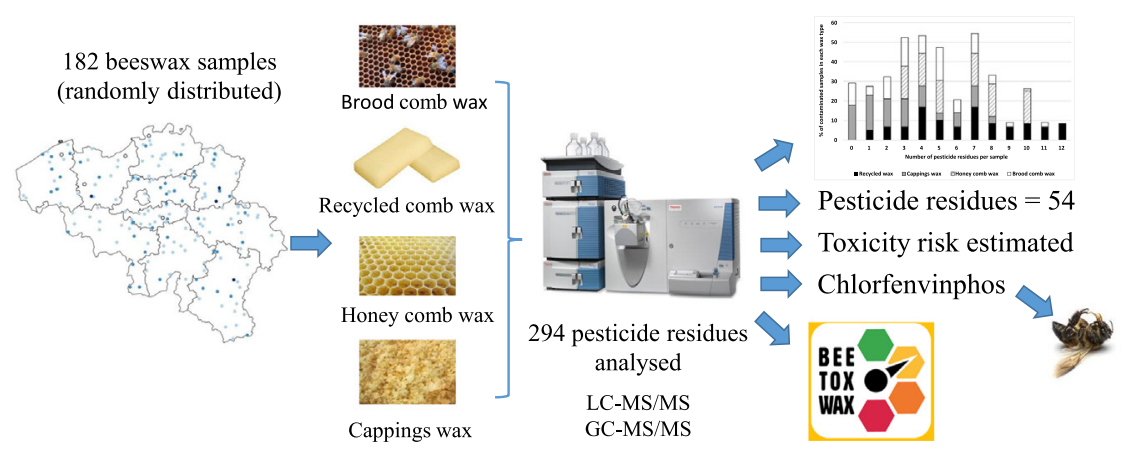

\begin{abstract}
A B S T R A C T
Pesticide and veterinary drug residues are one of the stress factors affecting bee health and mortality. To investigate the occurrence, the concentration and the toxicity risk to bees of pesticide residues in four different types of beeswax (brood comb wax, recycled comb wax, honey comb wax, and cappings wax), 182 samples were collected from apiaries located all over the Belgian territories, during spring 2016 and analysed by LCMS/MS and GC-MS/MS for the presence of 294 chemical residues. The toxicity risk to bees expressed as the Hazard Quotient (HQ) was calculated for each wax sample, according to two scenarios with different tau-fluvalinate $\mathrm{LD}_{50}$ values. Residues showing the highest prevalence were correlated to bee mortality in a multivariate logistic regression model and a risk-based model was used to predict colony bee mortality. Altogether, 54 different pesticide and veterinary drug residues were found in the four types of beeswax. The residues with a higher likelihood to be retained in beeswax are applied in-hive or with a high lipophilic nature. The multivariate logistic regression model showed a statistically significant influence of chlorfenvinphos on bee mortality. All our results indicated that cappings wax was substantially less contaminated. This national survey on beeswax contamination provides guidelines on the re-use of beeswax by beekeepers and shows the necessity to introduce maximum residue levels
\end{abstract}

\footnotetext{
* Corresponding author.

E-mail address: claude.saegerman@uliege.be (C. Saegerman).
} 
Chlorfenvinphos Hazard Quotient Risk assessment

Toxicity

Modelling for global trade in beeswax. An online tool was developed to enable beekeepers and wax traders to estimate the risk to honey bee health associated with contaminated wax.

(C) 2020 Elsevier B.V. All rights reserved.

\section{Introduction}

The presence of residues in apicultural matrices reflects anthropogenic activities whether they come from agricultural use or veterinary treatments (Balayiannis and Balayiannis, 2008; Berthoud et al., 2010). Honey bees and other pollinators are at risk from multiple stress factors (Berthoud et al., 2010; Dainat et al., 2012; Goulson et al., 2015; Le Conte et al., 2010; Van Engelsdorp et al., 2008) and pesticide residues play an undeniable role. The contribution of pesticide residues to the global decline of honey bees and other pollinators has lately received much attention from the scientific community (Mitchell et al., 2017; Tsvetkov et al., 2017; Woodcock et al., 2017). Since the arrival of the parasitic mite Varroa destructor in Belgium in 1984, the most common means of controlling Varroa has been through the use of synthetic acaricides (Bogdanov et al., 1998; Mullin et al., 2010). Treatments are placed in-hive, thus exposing not only the mites to the compound but honey bee eggs, larvae, adults, and beehive products. Residues acute toxicity to honey bees is characterised by the determination of the acute median lethal dose $\left(L_{50}\right)$ values, which is the residue dose that is required to kill half of the tested animals. $\mathrm{LD}_{50}$ values may differ based on the route of exposure and species exposed (Haschek et al., 2013).

Regarding adult honey bees, residues associated with acute contact $\mathrm{LD}_{50}$ values inferior to $2 \mu \mathrm{g}$ bee ${ }^{-1}$ are considered as highly toxic, moderately toxic with acute contact $\mathrm{LD}_{50}$ values between 2 and $10.99 \mu \mathrm{g}$ bee $^{-1}$, slightly toxic with acute contact $\mathrm{LD}_{50}$ values between 11 and $100 \mu \mathrm{g}$ bee $^{-1}$, and essentially non-toxic with acute contact $L_{50}$ values higher than $100 \mu \mathrm{g}$ bee $^{-1}$ (Washington State Department of Agriculture, 2010). The persistence of a residue depends on its physical and chemical properties (partition coefficients, degradation rates, deposition rates) and the characteristics of the contaminated matrix. Honey bees are typically exposed to a cocktail of residues; in-hive (beekeeper applied) acaricides and other veterinary drugs applied over long-time periods and out-of-hive (farmer applied) pesticides encountered in pollen, nectar, and water during their foraging activity (Bogdanov, 2006; Chauzat et al., 2011; Rortais et al., 2005). These pesticide residue mixtures may act alone or in interaction (Carnesecchi et al., 2019), in ways currently difficult to predict, potentially creating a toxic environment for honey bee growth and development (Tomé et al., 2020; Yao et al., 2018; Zhu et al., 2014).

Beeswax is a natural honey bee product. It is secreted in liquid form by special wax glands in the abdomen of younger worker bees (aged between 12 and 18 days) (Bogdanov, 2016) and solidifies into translucent white scales when in contact with air. Wax combs are constructed from these wax scales, molded into shape by honey bee mandibles. In Europe, as wax production is not the aim in beekeeping, beekeepers provide bee colonies with manufactured wax sheets of foundation, which the bees draw out into the full depth comb. The raw materials for wax manufacture are recycled from old brood combs, honey combs and cappings wax. Cappings wax contains almost exclusively pure wax. Beeswax is a complex mixture consisting mainly of esters of higher fatty acids (Aichholz and Lorbeer, 1999; Tulloch, 1980). Due to its high composition in fatty acids, and as most acaricides are fat-soluble and nonvolatile (Wallner, 1999), beeswax is a relevant matrix to assess inhive chemical exposure history for lipophilic compounds (Lozano et al., 2019; Ravoet et al., 2015). Of all beehive products, it has the lowest replacement rate, can remain in the hive for many years and is recycled by the beekeepers into new wax foundations for comb building, thus leading to a greater accumulation of different pesticide residues used in beekeeping and agriculture (Chauzat and Faucon, 2007; Mullin et al., 2010). Beeswax can be considered as a contaminant reservoir (Yáñez et al., 2013) or a final sink (Bommuraj et al., 2019). Even though most residues remain in the wax, residues migration from the wax to beebread, and larvae is a crucial factor that could affect the evolution of the colony (Murcia Morales et al., 2020). A residue accumulation can affect worker honey bee and queen development (Haarmann et al., 2002), bee longevity (Wu et al., 2011), and colony performance (Desneux et al., 2007).

Assessment/registration authorities like e.g. World Health Organisation (WHO), United States Environmental Agency (EPA), European Food Safety Authority (EFSA), and European Medicines Agency (EMA) ensure that each registered pesticide/veterinary drug continues to meet the highest standards of safety to protect human health and the environment. Within this context, older pesticides are being reviewed to ensure that they meet current scientific and regulatory standards. As an example, EPA screening-level assessors re-evaluated in 2005 tau-fluvalinate, one of the acaricides frequently used for Varroa control and reset its median acute contact lethal dose $\left(\mathrm{LD}_{50}\right)$ at $0.2 \mu \mathrm{g}$ bee $^{-1}$ (EPA, 2005). This classifies tau-fluvalinate as highly toxic to honeybees. Tau-fluvalinate is expected to pose an acute health risk to non-target insects. Nevertheless, in Europe, the acute $\mathrm{LD}_{50}$ of tau-fluvalinate is still set at $12 \mu$ bee $^{-1}$ (worst case from 24,48 and 72 -hour values) reported by the University of Hertfordshire Pesticide Properties DataBase (PPDB) (Lewis et al., 2016).

The European legislation on animal by-products (ABPs) defines beeswax as an "apiculture product" used in beekeeping (Regulation (EC) No 1774/2002) and categorises beeswax as an ABP Category 3 material, i.e. not intended for human consumption (Regulation EC No 1069/2009). This categorisation does not prevent the presence of contaminants and/or adulterants. Moreover, it allows the commercialisation of beeswax used in apiculture without previous quality (authenticity) control. In Belgium, the guidelines contained in the advice 18-2018 (Scientific Committee of the FASFC, 2018) set the limits for pesticide and veterinary drug residues at 9 different products and proposed limiting the sale of re-melted beeswax that exceeds these limits.

This first national pilot survey aimed to improve our understanding of the pesticide residues currently present, their rate of occurrence, and their concentration in four types of beeswax. The survey also aimed to assess the exposure risk to honey bees, comparing the toxicity of pesticide residues in the four beeswax types and the potential implications for beekeeping management practices.

The results obtained led us to develop an online tool (BeeToxWax) to empower beekeepers and wax traders to estimate the risk to honey bees associated with contaminated wax based on the residue concentrations reported in a laboratory analysis report and the pesticide residues acute $\mathrm{LD}_{50}$. The tool gives automated real-time recommendations on whether the tested sample can be reused in a colony or should be discarded based on the current scientific literature: contact Hazard Quotient (HQ) value over 250 are considered to have significant toxicity and elevated toxicity is associated with HQ values over 5000 (Traynor et al. 2016). The tool is a web-based calculator of risk associated with contaminated wax; its use could be an important strategy to sanitize beeswax available in the commercial trade stream (https://www.beetools. uliege.be). 


\section{Materials and methods}

\subsection{Beeswax and residues}

\subsubsection{Origin and characterisation of the wax samples}

A total of 200 beekeepers were randomly selected from the Federal Agency for the Safety of the Food Chain (FASFC) beekeepers database including 4949 registered beekeepers in 2015. Beeswax wax collected from a single hive out of one apiary per beekeeper during spring 2016. The number of beekeepers was stratified by province. Out of the selected beekeepers $(N=200), 91.5 \%$ of the beekeepers provided a wax sample of sufficient amount (100 g) for analysis (182 samples). Wax samples were differentiated into four types: brood $\operatorname{comb}^{1}$ wax $(N=$ $89)$, recycled $\operatorname{comb}^{2}$ wax $(N=59)$, honey $\operatorname{comb}^{3}$ wax $(N=6)$, and cappings ${ }^{4}$ wax $(N=28)$. The different types of waxes are easily identifiable by colour, shape, and consistency. Brood combs are dark, honey combs are light with no pupal cocoons, cappings wax is cut off comb when extracting honey and melted wax is received as a block or pressed into sheets of foundation. Beekeepers donated less honey comb wax as they reuse these light coloured frames for honey production. The samples were free of beebread, honey or brood, they were kept in hermetic plastic bags and stored at $-20{ }^{\circ} \mathrm{C}$ until analysis.

\subsubsection{Multi-residue analysis}

Analysis of beeswax was carried out at an independent laboratory in Germany (Intertek Food Services $\mathrm{GmbH}$ ) according to the European EN 15662 method (CEN 2008), between October 2016 and January 2017, using a common analytical protocol (QuEChERS) designed for the analysis of food materials and suitably adapted. All residues were analysed using multi-residue GC-MS/MS and LC-MS/MS methods covering 294 different substances with detection limits (LOD) of $0.003 \mathrm{mg} / \mathrm{kg}$ and limits of quantification (LOQ) of $0.01 \mathrm{mg} / \mathrm{kg}$ in most cases and with recoveries between $70 \%$ and $120 \%$. The quality control is done using quality control samples and spiking experiments.

Generally, $10 \mathrm{ml}$ of deionized water (BarnsteadTM, Nanopure DiamondTM, Thermo Scientific) was added to approximately $5 \mathrm{~g}$ of beeswax accurately weighed into a $50 \mathrm{ml}$-Teflon centrifuge tube. $10 \mathrm{ml}$ of acetonitrile (HPLC Gradient Grade, VWR) was added together with an internal standard solution containing isoproturon-d6 for LCMS/MS analysis, anthracene-d10 for GC-MS/MS analysis and octachlorostyrene for negative chemical ionization GC-MSD analysis.

The whole preparation was mixed using a horizontal shaker for 20-30 min. Then $6.5 \mathrm{~g}$ QuEChERS salt mixture was added, consisting of $4 \mathrm{~g}$ of anhydrous magnesium sulfate, $1 \mathrm{~g}$ of sodium chloride, $1 \mathrm{~g}$ of trisodium citrate dihydrate and $0.5 \mathrm{~g}$ of disodium hydrogen citrate sesquihydrate, and the whole was mixed by hand for approximately $1 \mathrm{~min}$, then centrifuged for $13 \mathrm{~min}$ at 10,000 Relative Centrifugal Force (RCF; refrigerated centrifuge Rotina $380 \mathrm{R}$ ). $7 \mathrm{ml}$ of the supernatant was transferred to a tube containing $1 \mathrm{~g}$ of anhydrous calcium chloride and $300 \mathrm{mg}$ of PSA as a sorbent. After briefly shaking by hand, this mixture was centrifuged again for $13 \mathrm{~min}$ at 10,000 RCF. $1 \mathrm{~mL}$ of the supernatant was then removed for LC-MS/MS analysis. Further two aliquots of $1 \mathrm{ml}$ each were filled into vials and $8 \mu \mathrm{l}$ of $5 \%$ formic acid solution in acetonitrile were added as analyte protectant for GC-MS/MS and GC-MSD analyses, respectively. The addition of $5 \%$ formic acid solution in acetonitrile is done to stabilize the analytes in the solution. This is not meant as a classical Analyte Protectants (AP) for GC-MS analysis. An AP-Mix (mixture of 3-Ethoxypropandiol, Shikimic acid, Glucuronolactone and Sorbitol) for GC-MS analysis was used to block free active spaces on the liner to prevent interactions between the liner and the analytes.

\footnotetext{
1 Wax comb in which the brood was reared.

Melted old brood and/or honey wax comb to be reused.

${ }^{3}$ Wax comb in which honey was stored.

${ }^{4}$ Virgin wax covering on sealed honey combs rendered by beekeepers.
}

LC-MS/MS was performed on a Thermo Scientific system consisting of an Accela 1250 pump and a TSQ Quantum Access mass spectrometer with a Hypersil Gold C8 $(150 \times 2.1 \mathrm{~mm}, 5 \mu \mathrm{m})$ column. The GC-MS/MS system was a GC 7890 equipped with a HP-5 ms column ( $30 \mathrm{~m} \times 0.25 \mathrm{~mm} \times 0.25 \mu \mathrm{m}$, Varian) combined to a 7000 Triple Quadrupole mass spectrometer (Agilent Technologies). The GC-MSD system consisted of a GC $6890 \mathrm{~N}$ with a VF-5 ms column (30 $\mathrm{m} \times 0.25 \mathrm{~mm} \times 0.25 \mu \mathrm{m}$, Varian) combined to a $5975 \mathrm{XL}$ inert MS (Agilent Technologies).

\subsubsection{Regression modelling of residue per wax type}

In a first step, a descriptive analysis was performed to examine data for completeness and validity and to identify the wax type with the least residues. After this validation, a univariate logistic regression model was performed for each residue $(N=54)$ to examine associations between a range of independent variables (i.e. the four wax types, with cappings wax considered as the purest reference wax) and the outcome of interest (each residue). The level of statistical significance was set to $P=$ 0.05 .

\subsubsection{Hazard Quotient and toxicity to bees}

To estimate contaminated wax contact toxicity to bees, a mean Hazard Quotient (HQ) was calculated for each of the four wax types. Until now, toxicity for larvae has not been well studied. As chronic median lethal dose data for bees are extremely rare (EFSA, 2012), the acute contact median lethal dose $\left(\operatorname{LD}_{50} 48 \mathrm{~h}\right.$ for adult bees) was used in the HQ calculation. Per sample then gathered by wax type, HQ was calculated as the sum of the concentration of the residue $\left(\mathrm{mg} \mathrm{kg}^{-1}\right)$ divided by its respective acute contact $\mathrm{LD}_{50}\left(\mu \mathrm{g}\right.$ bee $\left.^{-1}\right)$. The HQ provides an estimate based on percentages of $\mathrm{LD}_{50}$ equivalents present in the wax. For oral contact in pollen instead of beeswax, HQ is considered notable when it is $>50$ and is considered as elevated when it is $>500$ (Stoner et al., 2013). In beeswax, pesticide residues are embedded in the matrix and not all residues are in contact with honey bees. Only a fraction of the pesticide load is exposed to the individuals of the colony, so HQ in beeswax samples was considered as notable when $>250$ (Calatayud-Vernich et al., 2019). Samples with contact HQ beeswax $>5000$ were considered to have an elevated pesticide load (Traynor et al., 2016).

Acute contact $\mathrm{LD}_{50}$ values were retrieved from the Pesticide Properties DataBase (PPDB) and the Veterinary Substances DataBase (VSDB) reported by the University of Hertfordshire (Lewis et al., 2016) or from some additional primary literature (Sanchez-Bayo and Goka, 2014; Stoner et al., 2013) (Table 1). For substances with multiple $\mathrm{LD}_{50}$, the lowest value was considered according to a conservative scenario. For unknown contact $\mathrm{LD}_{50}$, when possible, the $\mathrm{LD}_{50}$ of the respective parent compound was used in the HQ calculation acknowledging that some metabolites may have either lower or higher toxicity than the parent compound (Suchail et al., 2001). When the substance was not assimilated to a pesticide (e.g. solvent), a low toxicity value of $200 \mu \mathrm{g}$ bee $^{-1}$ was assigned. In the case of tau-fluvalinate, both values proposed by the EPA $\left(0.2 \mu \mathrm{g} \mathrm{be}^{-1}\right)$ and PPDB $\left(12 \mu \mathrm{g} \mathrm{bee}^{-1}\right)$ were considered in two toxicity scenarios as an important 60 -fold disparity appeared with its toxicity.

Cumulative risk by contact exposure estimate.

To assess the risk to larvae in contact with contaminated wax topical contact during their development, it is necessary to consider the frequency of detection of each pesticide residue in this matrix, because prevalence indicates the probability of exposure to the contaminants. We used the method suggested by Sanchez-Bayo and Goka (SanchezBayo and Goka, 2014) that takes into consideration the cell weight (0.0232 g) (El Agrebi et al., 2019) and the development time (21 days) of bee larvae (Eq. (1)). 
Table 1

Residue levels of pesticides found in the four types of beeswax in Belgian apiaries. The type of each active substance, the contact acute median lethal dose and number of positive samples found are reported.

\begin{tabular}{|c|c|c|c|c|c|c|c|c|c|c|c|c|c|}
\hline \multirow[t]{2}{*}{ Active ingredient } & \multicolumn{4}{|c|}{ Active ingredient type } & \multicolumn{3}{|c|}{$\begin{array}{l}\text { Contact acute } 48 \text { h LD50 } \\
\text { ( } \mu \text { g bee- } 1 \text { ) }\end{array}$} & \multicolumn{5}{|c|}{$\begin{array}{l}\text { Brood comb wax } \\
(n=89)\end{array}$} & \multirow{2}{*}{$\begin{array}{l}\begin{array}{l}\text { Recycled } \\
\text { comb wax } \\
(n=59)\end{array} \\
\begin{array}{l}\text { Frequency } \\
(\%)\end{array}\end{array}$} \\
\hline & Insecticide & Fungicide & Acaricide & Other & PPDB/VSDB & $\begin{array}{l}\text { Stoner et al., } \\
2013\end{array}$ & $\begin{array}{l}\text { Sanchez-Bayo and } \\
\text { Goka, } 2014\end{array}$ & $\begin{array}{l}\text { \# positive } \\
\text { samples }\end{array}$ & $\begin{array}{l}\text { Frequency } \\
(\%)\end{array}$ & $\begin{array}{l}\text { Mean } \\
(\mathrm{mg} / \mathrm{kg})\end{array}$ & $\begin{array}{l}\operatorname{Min} \\
(\mathrm{mg} / \mathrm{kg})\end{array}$ & $\begin{array}{l}\operatorname{Max} \\
(\mathrm{mg} / \mathrm{kg})\end{array}$ & \\
\hline Acrinathrin & $\mathrm{x}$ & & $\mathrm{x}$ & & 0.084 & & 0.17 & 1 & $1.1 \%$ & 0.014 & 0.014 & 0.014 & 1.7 \\
\hline Amitraz (incl. Metabolites) & $\mathrm{x}$ & & $\mathrm{x}$ & Antiparasite & 50 & & & 25 & 28.1 & 0.740 & 0.010 & 16.7 & 16.9 \\
\hline Azoxystrobin & & $\mathrm{x}$ & & & 200 & 200 & & 3 & 3.4 & 0.047 & 0.011 & 0.117 & 1.7 \\
\hline Biphenyl & $\mathrm{X}$ & $\mathrm{x}$ & $\mathrm{x}$ & & 1 & & & & & & & & 1.7 \\
\hline Boscalid & & $\mathrm{x}$ & & & 200 & 200 & & 5 & 5.6 & 0.121 & 0.038 & 0.310 & 11.9 \\
\hline Bromopropylate & & & $\mathrm{x}$ & & / & & & 22 & 24.7 & 0.024 & 0.010 & 0.058 & 39.0 \\
\hline Captan & & $\mathrm{X}$ & & Bactericide & 200 & & & 3 & 3.4 & 0.646 & 0.014 & 1.837 & 8.5 \\
\hline Carbendazim & & $\mathrm{x}$ & & Metabolite & 50 & 50 & & 6 & 6.7 & 0.040 & 0.014 & 0.098 & \\
\hline Chlorfenvinphos & $\mathrm{x}$ & & $\mathrm{x}$ & Sheep dip & 1 & & 4.1 & 20 & 22.5 & 0.036 & 0.012 & 0.084 & 32.2 \\
\hline Chloropropylate & $\mathrm{x}$ & & $\mathrm{x}$ & & i & & & 2 & 2.2 & 0.024 & 0.011 & 0.036 & 5.1 \\
\hline Chlorothalonil & & $\mathrm{x}$ & & & 101 & & 135.32 & 1 & 1.1 & 0.066 & 0.066 & 0.066 & \\
\hline Chlorpropham & & & & Herbicide & 86 & & & 3 & 3.4 & 0.034 & 0.025 & 0.053 & 25.4 \\
\hline Chlorpyrifos (-ethyl) & $\mathrm{x}$ & & & & 0.059 & 0.01 & 0.07 & 12 & 13.5 & 0.025 & 0.011 & 0.041 & 11.9 \\
\hline Coumaphos & $\mathrm{x}$ & & $\mathrm{x}$ & Antiparasite & 1 & 24 & 20.29 & 72 & 80.9 & 0.150 & 0.010 & 2.257 & 89.8 \\
\hline Cypermethrin & $\mathrm{x}$ & & & Sheep dip & 0.02 & & 0.03 & 4 & 4.5 & 2.34 & 0.023 & 9.300 & \\
\hline Cyprodinil & & $\mathrm{x}$ & & & 784 & 784 & & 2 & 2.2 & 0.063 & 0.062 & 0.063 & 10.2 \\
\hline $\begin{array}{l}\text { p,p'-DDE } \\
\text { (Dichlorodiphenyldichloroethylene) }\end{array}$ & & & & Metabolite & l & & & & & & & & 1.7 \\
\hline DDT (Sum, expressed as DDT) & $\mathrm{x}$ & & & & 0.54 & & & & & & & & 1.7 \\
\hline$o, p^{\prime}-$ DDT & & & & Isomer & 0.54 & & & & & & & & 3.4 \\
\hline p,p'-DDT (Chlorophenothane) & $\mathrm{x}$ & & & & 0.54 & & & 1 & 1.1 & 0.010 & 0.010 & 0.010 & 8.5 \\
\hline DEET (diethyltoluamid) & $\mathrm{x}$ & & & Repellent & 1 & & & 23 & 25.8 & 0.102 & 0.010 & 0.707 & 52.5 \\
\hline Deltamethrin & $\mathrm{x}$ & & & Metabolite & 0.0015 & & 0.02 & & & & & & 1.7 \\
\hline Diazinon & $\mathrm{x}$ & & $\mathrm{x}$ & Repellent & 0.13 & 0.22 & 0.38 & & & & & & 3.4 \\
\hline
\end{tabular}




\begin{tabular}{|c|c|c|c|c|c|c|c|c|c|c|c|c|c|}
\hline Dibromobenzophenone & & & & Metabolite & Not listed & & & 3 & 3.4 & 0.013 & 0.010 & 0.015 & 1.7 \\
\hline Dichlofluanid & & $\mathrm{x}$ & & & 16 & & & 3 & 3.4 & 0.174 & 0.012 & 0.494 & 11.9 \\
\hline Dichlorobenzophenone & & & & Metabolite & Not listed & & & & & & & & \\
\hline Dimethomorph & & $\mathrm{x}$ & & & 102 & 10 & & 2 & 2.2 & 0.285 & 0.046 & 0.523 & \\
\hline Dimoxystrobin & & $\mathrm{x}$ & & & 100 & & & 1 & 1.1 & 0.022 & 0.022 & 0.022 & \\
\hline Etridiazole & & $\mathrm{x}$ & & & 1 & & & & & & & & 1.7 \\
\hline Fenpyroximate & & & $\mathrm{x}$ & & 15.8 & & & 8 & 9.0 & 0.029 & 0.010 & 0.064 & 6.8 \\
\hline tau-Fluvalinate & $\mathrm{x}$ & & $\mathrm{x}$ & & 12 & 0.2 & 8.66 & 82 & 92.1 & 0.530 & 0.010 & 6.460 & 94.9 \\
\hline Hexythiazox & & & $\mathrm{x}$ & & 200 & & & 9 & 10.1 & 0.015 & 0.010 & 0.030 & 3.4 \\
\hline Iprodione & & $\mathrm{x}$ & & & 200 & & & 10 & 11.2 & 0.058 & 0.010 & 0.130 & 22.0 \\
\hline Lindane $(\gamma-\mathrm{HCH})$ & $\mathrm{x}$ & & $\mathrm{x}$ & & 0.23 & & & 1 & 1.1 & 0.023 & 0.023 & 0.023 & 8.5 \\
\hline Metalaxyl & & $\mathrm{x}$ & & & 200 & 100 & & 1 & 1.1 & 0.015 & 0.015 & 0.015 & \\
\hline Methoxychlor & $\mathrm{x}$ & & & & 23.6 & & & & & & & & 3.4 \\
\hline Parathion & $\mathrm{x}$ & & $\mathrm{x}$ & & l & & & 1 & 1.1 & 0.016 & 0.016 & 0.016 & \\
\hline Pendimethalin & & & & Herbicide & 100 & 49.8 & & 5 & 5.6 & 0.017 & 0.012 & 0.030 & \\
\hline Pentachloroanisole & & & & $\begin{array}{l}\text { Metabolite } \\
\text { Pentachlorophenol }\end{array}$ & 48 & & & 6 & 6.7 & 0.026 & 0.010 & 0.065 & 23.7 \\
\hline Permethrin (Sum all Isomere) & $\mathrm{x}$ & & & Antiparasite & 0.29 & & 0.06 & 12 & 13.5 & 0.077 & 0.011 & 0.311 & 27.1 \\
\hline 2-phenylphenol & & $\mathrm{X}$ & & Other substance & 1 & & & 17 & 19.1 & 0.022 & 0.010 & 0.074 & 8.5 \\
\hline Piperonyl butoxide & & & & Performance enhancer & 294 & & & 20 & 22.5 & 0.055 & 0.010 & 0.376 & 40.7 \\
\hline Pirimicarb & $\mathrm{x}$ & & & & 53.1 & 12.56 & & 2 & 2.2 & 0.014 & 0.011 & 0.016 & \\
\hline Propamocarb & & $\mathrm{x}$ & & & 100 & & & 3 & 3.4 & 0.018 & 0.010 & 0.027 & 1.7 \\
\hline Propargite & & & $\mathrm{x}$ & & 47.9 & & & 51 & 57.3 & 0.124 & 0.011 & 0.375 & 57.6 \\
\hline Propiconazole & & $\mathrm{x}$ & & & 100 & 25 & & 1 & 1.1 & 0.378 & 0.378 & 0.378 & 3.4 \\
\hline Pyridaben & $\mathrm{x}$ & & $\mathrm{x}$ & & 0.024 & & 0.05 & 1 & 1.1 & 0.010 & 0.010 & 0.010 & \\
\hline Pyrimethanil & & $\mathrm{x}$ & & & 100 & 100 & & 3 & 3.4 & 0.048 & 0.012 & 0.080 & 11.9 \\
\hline Tebuconazole & & $\mathrm{x}$ & & Plant growth regulator & 200 & & & & & & & & 1.7 \\
\hline Tetradifon & $\mathrm{x}$ & & $\mathrm{x}$ & & 11 & & & & & & & & 5.1 \\
\hline Tetramethrin & $\mathrm{x}$ & & & & 1 & & & & & & & & 1.7 \\
\hline Thiacloprid & $\mathrm{x}$ & & & Molluscicide & 38.82 & 37.83 & & 2 & 2.2 & 0.030 & 0.014 & 0.046 & 1.7 \\
\hline Trifloxystrobin & & $x$ & & & 100 & 200 & & 1 & 1.1 & 0.025 & 0.025 & 0.025 & \\
\hline Vinclozolin & & $\mathrm{x}$ & & & / & & & & & & & & 1.7 \\
\hline
\end{tabular}

Legend: Amitraz, including the metabolites DMPF, DMF and the 2,4 -dimethylaniline moiety; PPDB/VSDB, data was retrieved from Pesticide Properties DataBase and Veterinary Substances DataBase (Lewis et al., 2016). 
Risk $\%=\left(\frac{\text { Frequency } \% \mathrm{x} \text { Residue concentration }[\mu \mathrm{g} / \mathrm{g}]}{\mathrm{LD}_{50} \text { acute contact }\left[\mu \mathrm{g} \text { bee }^{-1}\right]}\right) \times 0,023[\mathrm{~g}] \times 21[$ days $]$

$$
\begin{gathered}
\text { Cumulative risk }_{P 1-P 54 \%=\sum_{P=1}^{54}}\left(\frac{\text { Frequency } \% \mathrm{x} \text { Residue concentration }[\mu \mathrm{g} / \mathrm{g}]}{\mathrm{LD}_{50} \text { acute contact }\left[\mu \mathrm{g} \mathrm{bee}^{-1}\right]}\right) \\
\times 0,023[\mathrm{~g}] \times 21[\text { days }]
\end{gathered}
$$

Eq. (1) indicates the percentage of risk (i.e. likelihood of causing 50\% mortality) caused by a given pesticide residue on honey bee larvae that come into contact with contaminated wax during their development. For each wax type, a cumulative risk by contact exposure was calculated as the summation of the risk caused by each pesticide in the sample (Eq. (2)). The cumulative risk expresses the risk that larvae would be exposed to during their development to a higher pesticide dose than the contact lethal dose $\left(\mathrm{LD}_{50}\right)$.

\subsection{Pesticide and veterinary drug residues and honey bee mortality}

\subsubsection{Data on bee mortality}

Sampling was conducted jointly with a questionnaire to record colony losses and management practices. The total loss rate was calculated by dividing the total number of colonies lost between September 2015 and April 2016 (winter and seasonal) by the number of colonies in September 2015 multiplied by 100 (Clermont et al., 2014) excluding removed, sold and purchased colonies. Bee mortality rate in function of the presence or the absence of a specific pesticide residue was tested with a two-sample Wilcoxon rank-sum (Mann-Whitney) test for significance. The limit of statistical significance of the test was defined as 0.05 .

\subsubsection{Logistic regression model}

A univariate logistic regression model was used to explain colony mortality expressed as a binary dependent variable, taking into account the acceptable level of mortality ( 0 for colony mortality rates $\leq 10 \%$; 1 for colony mortality rates $>10 \%$ (Morgenthaler, 1968)) associated with residues. Then, a multivariate logistic regression was performed using the most significant variables $(P<0.1)$ out of the univariate model. Finally, in a backward stepwise multivariate model, the least significant variable (with the highest $P$ value) were eliminated in a step-by-step approach. At each stage, a likelihood ratio test was used to compare the complex and simplified models. When there was no significant difference between them (using value of $P>0.10$ ), the simplified model was used. The interaction between variables in the multivariate final retained model was tested. All models and tests were performed using Stata SE $14.1{ }^{\circledR}$ (StataCorp LP, College Station, TX, USA) and the limit of statistical significance of performed tests was defined as 0.05 .

\subsubsection{Development of a risk-based model}

To predict the colony mortality expressed as a binary variable ( 0 for colony mortality rates $\leq 10 \%$; 1 for colony mortality rates $>10 \%$ ) in function of the different combinations of pesticide residues present in each beeswax sample, a Receiver Operating Characteristic (ROC) curve was established. For this, only the 10 residues with a $P$-value $<0.20$ in the previous univariate logistic regression analysis were retained. Next, ten different receivers operating characteristic (ROC) curves were established (i.e. with the first, the two first, the three first, until the ten-first pesticide residues retained). The ROC is a probability curve that plotted with true-positive results (Y-Axis) against the falsepositive results (X-Axis). Each point of the curve is determined by a specific threshold $=$ cut-off (i.e. a certain combination of pesticide residues). The area under the ROC curve (AUC) is the performance measurement for the classification test at various threshold settings.
Higher the AUC, better the test can distinguish between colony mortality status ( 0 for colony mortality rates $\leq 10 \%$; 1 for colony mortality rates $>10 \%$ ). Indeed, the ROC curve with the higher AUC (among the ten tested) was retained to determine the best cut-off (i.e. optimal number of residues in combination) related to the bee colony mortality.

\subsubsection{The number of residues per wax type}

The relationship between the number of residues and the type of beeswax was assessed using a negative binomial regression due to the over-dispersion of the variable outcome. Possible residue synergies were looked for in residue combinations.

\section{Results}

\subsection{Beeswax, pesticides and veterinary drug residues}

Descriptive data of the residues found in Belgian beeswax are presented in Table 1 . The analysed samples revealed a contamination prevalence of $97.3 \%$ and the presence of 54 different compounds for all wax types jointly. Per sample, the number of different residues ranged from 1 to 12 with a median value of 5 . Ten different residues were commonly found in the four wax types. Acaricides (i.e. tau-fluvalinate and coumaphos) have the highest prevalence in all wax types (respectively $89.6 \%$ and $78.6 \%$ ), followed by propargite, chlorfenvinphos, bromopropylate (including metabolite 4,4'-Dibromo-benzophenone). Also, the insecticide permethrin, the repellent DEET (diethyltoluamide), the fungicide pentachloroanisole, and its metabolite pentachlorophenol, as well as the performance enhancer substance piperonyl butoxide were frequently found in the wax samples. The frequency of occurrence of each residue per wax type is shown in Table 1 . The percentage of contaminated samples as a function of the number of residues per wax type is shown in Fig. 1. This percentage is significantly higher in cappings wax for lower residue numbers than in the other wax types (Negative binomial regression; $P<0.001$ ).

\subsection{Frequency of pesticide and veterinary drug residues per wax type}

\subsubsection{Brood comb wax}

A total of 41 different residues were found in brood comb wax $(N=$ 89). The median number of different residues per sample was 5 (minmax, 1-12). Residues with the highest prevalence were tau-fluvalinate (92.1\%), coumaphos (80.9\%), propargite (57.3\%), amitraz (28.1\%), and DEET (25.8\%). The highest maximum concentrations were observed for amitraz (including the metabolites containing the 2,4dimethylaniline expressed as amitraz) with $16.7 \mathrm{mg} \mathrm{kg}^{-1}$ followed by cypermethrin $\left(9.3 \mathrm{mg} \mathrm{kg}^{-1}\right)$, and by tau-fluvalinate $\left(6.46 \mathrm{mg} \mathrm{kg}^{-1}\right)$. Seven highly toxic residues to bees (with $\mathrm{DL}_{50}<2 \mu \mathrm{g}$ bee $^{-1}$ ) were found: chlorpyrifos (-ethyl) and permethrin, both in $13.5 \%$ of the samples, cypermethrin in $4.5 \%$ of the samples, acrinathrin, lindane, p, $\mathrm{p}^{\prime}$ DDT, and pyridaben in $1.1 \%$ of the samples. The neonicotinoid thiacloprid was detected in $2.2 \%$ of the sample with a maximum concentration of $0.046 \mathrm{mg} \mathrm{kg}^{-1}$ (Table 1 ).

Increased odds of tau-fluvalinate were observed in brood comb wax compared with reference cappings wax (OR $=5.36$ with 95\% CI: 1.82-15.73; $P=0.002$ ) (Table 2).

\subsubsection{Recycled comb wax}

In recycled comb wax $(N=59), 42$ different residues were quantified. The median number of different residues per sample was 7 (minmax: 1-12). Residues with the highest prevalence were taufluvalinate (94.4\%), coumaphos (89.8\%), propargite (57.6\%), DEET (52.5\%), Piperonyl butoxide (40.7\%), bromopropylate (39\%), chlorfenvinphos (32.2\%), permethrin (27.1\%), chlorpropham (25.4\%) and pentachloroanisole (23.7\%). Tau-fluvalinate had the highest concentration with $8.68 \mathrm{mg} \mathrm{kg}^{-1}$ followed by coumaphos with $7.41 \mathrm{mg}$ $\mathrm{kg}^{-1}$ and chlorpyrifos (-ethyl) with $4.38 \mathrm{mg} \mathrm{kg}^{-1}$ (Table 1 ). Highly toxic 


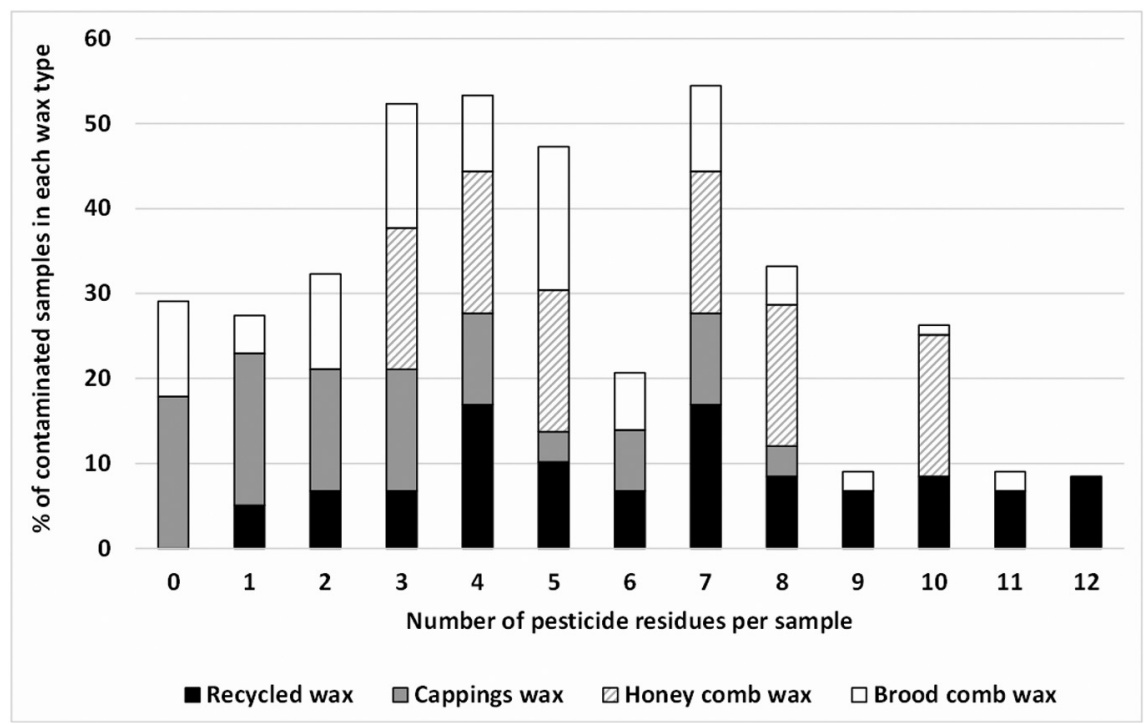

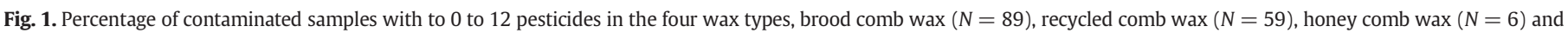
cappings wax $(N=28)$.

residues to bees (with $\mathrm{DL}_{50}<2 \mu \mathrm{g} \mathrm{bee}^{-1}$ ) were found: permethrin in $27.1 \%$ of the samples, chlorpyrifos (-ethyl) in $11.9 \%$, p,p'-DDT and lindane in $8.5 \%$, dianizon in 3.4\%, cypermethrin, acrinathrin, deltamethrin, DDT and tetramethrin in $1.7 \%$ of the samples. The neonicotinoid thiacloprid was detected in one sample with a maximum concentration of $0.014 \mathrm{mg} \mathrm{kg}^{-1}$.

Increased odds of coumaphos were observed in recycled comb wax compared with reference cappings wax ( $\mathrm{OR}=10.19$ with $95 \% \mathrm{CI}$ : 3.31-31.37; $p=0.000$ ) (Table 2).

\subsubsection{Honey comb wax}

The results interpretations for this wax type are only indicative as they are derived from a comparatively smaller sample size. Honey comb wax $(N=6)$ contained 13 different pesticide residues, the median number of different residues per sample was 6 (min-max: 3-10). Tau-fluvalinate was detected in $100 \%$ of the samples, coumaphos, and propargite in $83.3 \%$ of the samples, piperonyl butoxide in $66.7 \%$, and fenpyroximate in $50 \%$ of the samples. Six molecules were found in $33.3 \%$ of the analysed samples, i.e. bromopropylate (and its metabolite

Table 2

Univariate logistic regression model outputs for residues detection rate in brood comb wax, in recycled comb wax and in honey comb wax with cappings wax as reference.

\begin{tabular}{|c|c|c|c|c|}
\hline Residue & Wax type & $\begin{array}{l}\text { Odds } \\
\text { ratio }\end{array}$ & $\begin{array}{l}95 \% \text { confidence } \\
\text { interval }\end{array}$ & P-value \\
\hline Brompropylat* & Recycled & 3.51 & $(1.13-10.86)$ & 0.03 \\
\hline $\begin{array}{l}\text { Chlorpyrifos } \\
\text { (-ethyl) }\end{array}$ & Honey comb & 31.67 & $(1.29-772.98)$ & 0.034 \\
\hline \multirow[t]{2}{*}{ Coumaphos } & Brood comb & 4.89 & $(1.96-12.15)$ & 0.001 \\
\hline & Recycled & 10.19 & $(3.31-31.37)$ & 0.000 \\
\hline Fenpyroximate & Honey comb & 57.00 & $(2.40-1349.32)$ & 0.012 \\
\hline Pentachloranisole & Recycled & 8.40 & $(1.04-67.51)$ & 0.045 \\
\hline \multirow[t]{2}{*}{ Piperonylbutoxide } & Recycled & 2.95 & $(1.02-8.52)$ & 0.046 \\
\hline & Honey comb & 7.69 & $(1.26-46.68)$ & 0.027 \\
\hline \multirow[t]{3}{*}{ Propargite } & Brood comb & 4.03 & $(1.55-10.44)$ & 0.004 \\
\hline & Recycled & 4.08 & $(1.50-11.08)$ & 0.006 \\
\hline & Honey comb & 15.00 & $(1.48-151.28)$ & 0.022 \\
\hline \multirow[t]{2}{*}{ tau-Fluvalinate } & Brood comb & 5.36 & $(1.82-15.73)$ & 0.002 \\
\hline & Recycled & 7.86 & $(2.08-29.71)$ & 0.002 \\
\hline
\end{tabular}

Legend: *An example of interpretation is presented: significant more detection of Brompropylat was found in recycled comb in comparison with the cappings wax as reference. Other beeswax types are not different from the reference.
4,4'-Dibromo-benzophenone), chlorfenvinphos, chlorpyrifos (-ethyl), pentachloranisole, and permethrin (Table 1). In honey comb, two insecticides considered as highly toxic to bees $\left(<2 \mu\right.$ bee $\left.^{-1}\right)$ were detected: permethrin and chlorpyrifos (-ethyl).

The highest maximum concentrations were observed for taufluvalinate with $0.91 \mathrm{mg} \mathrm{kg}^{-1}$ followed by DEET with $0.78 \mathrm{mg} \mathrm{kg}^{-1}$ and coumaphos with $0.45 \mathrm{mg} \mathrm{kg}^{-1}$. Two highly toxic residues to bees (with $\mathrm{DL}_{50}<2 \mu \mathrm{g}$ bee $^{-1}$ ) were detected: permethrin and chlorpyrifos (ethyl). No trace of thiacloprid (neonicotinoids) was detected in honey comb wax.

Increased odds of fenpyroximate were observed in honey comb wax compared with reference cappings wax (OR $=57$ with $95 \% \mathrm{CI}$ : $2.40-1349.32$ [wide range due to small sample size]; $P=0.012$ ) (Table 2).

\subsubsection{Cappings wax}

In cappings wax $(N=28), 18$ different residues were detected. The median number of different residues per sample was 3 (min-max: 0-8) (Table 1). Tau-fluvalinate (65.5\%), coumaphos (44.48\%), DEET (37.93\%), propargite $(24.1 \%)$ and piperonyl butoxide (17.2\%) were the most frequently detected residues in cappings wax. The highest maximum concentrations were observed for coumaphos with $0.93 \mathrm{mg} \mathrm{kg}^{-1}$ followed by tau-fluvalinate with $0.53 \mathrm{mg} \mathrm{kg}^{-1}$ and propargite with $0.45 \mathrm{mg} \mathrm{kg}^{-1}$. Permethrin (13.8\%) was the only substance found with high toxicity to bees. No trace of thiacloprid (neonicotinoids) was detected in cappings wax.

\subsection{Wax Hazard Quotient and toxicity to bees}

Overall, in the first scenario (tau-fluvalinate $\mathrm{DL}_{50}=12 \mu \mathrm{g}$ bee ${ }^{-1}$ ), out of $N=182,123$ samples of the samples (67.5\%) had a low HQ value $(<250), 55$ samples $(30.2 \%)$ had significant toxicity $(250<\mathrm{HQ}<5000)$ and 4 samples $(2.2 \%)$ of the total number of samples had elevated toxicity to bees (HQ> 5000) (Fig. 2). At the territorial level, the samples with the highest HQ $(N=4)$ were reported in the province of Luxembourg $(\max =466,246)$, in Limburg $(\max =5242$ and 74,208) and East Flanders ( $\max =17,536$ ) (Table 3 ). Detailed results per wax type are shown in Table 4 . With the second toxicity scenario (taufluvalinate $D L_{50}=0.2 \mu \mathrm{g}$ bee $^{-1}$ ), the HQ levels approach alarming levels and the number of samples exceeding the threshold values increases (Table 4). 


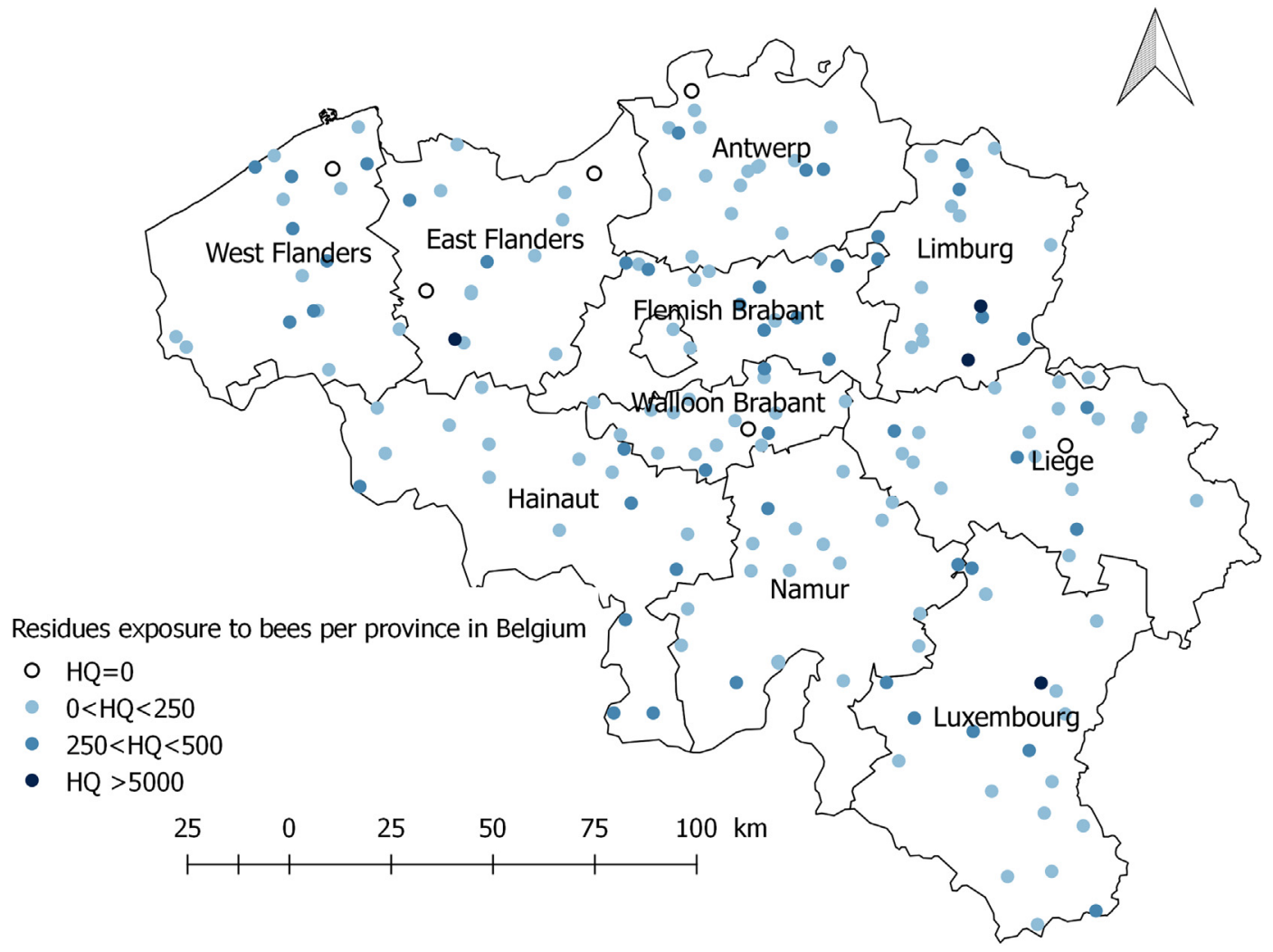

Fig. 2. Residues exposure risk to bees per province in Belgium $(N=182)$.

\subsection{Cumulative risk by contact exposure to bee larvae}

In the scenario where tau-fluvalinate mean $\mathrm{DL}_{50}=12 \mu \mathrm{g}$ bee ${ }^{-1}$ and considering the Eq. (2), the risk posed to bee larvae by the presence of residues in brood comb, recycled comb, honey comb, and cappings waxes is respectively of $15.12 \%, 12.3 \%, 4.79 \%$, and $0.73 \%$. With the second scenario (tau-fluvalinate $\mathrm{DL}_{50}=0.2 \mu \mathrm{g} \mathrm{bee}^{-1}$ ) the cumulative risk for bee larvae in the four wax types are respectively of $122 \%, 119 \%$, $104 \%$, and $16 \%$ (Table 4 ).

\subsection{Pesticide and veterinary drug residues and honey bee mortality}

\subsubsection{Logistic regression model}

An individual residue's possible correlation with mortality rates was tested using a univariate logistic regression model (Table 5). After multivariate logistic regression analysis, only chlorfenvinphos exhibited a significant correlation with bee mortality $(\mathrm{OR}=2.15 ; 95 \% \mathrm{CI}$ : 1.04-4.44; $P=0.038$ ). Moreover, no interaction between

Table 3

Hazard quotient values per province in Belgium.

\begin{tabular}{llllll}
\hline Provinces & Mean HQ & S.D. & Median HQ & Min HQ & Max HQ \\
\hline Antwerp & 79 & 150 & 14 & 0,0 & 533 \\
Eastern Flanders & 1494 & 4515 & 10 & 0,0 & 17,536 \\
Flemish Brabant & 369 & 273 & 2 & 0,6 & 837 \\
Hainaut & 482 & 769 & 189 & 3,0 & 2408 \\
Liège & 251 & 545 & 28 & 1,4 & 2295 \\
Limburg & 4996 & 17,896 & 131 & 4,1 & 74,208 \\
Luxemburg & 24,738 & 106,917 & 36 & 1,9 & 466,249 \\
Namur & 374 & 1085 & 22 & 0,1 & 4561 \\
Walloon Brabant & 108 & 157 & 44 & 0,2 & 501 \\
Western Flanders & 266 & 337 & 86 & 0,0 & 1081 \\
\hline
\end{tabular}

Legend: S.D., standard deviation; HQ Hazard quotient, Min, minimum; Max, maximum. chlorfenvinphos and permethrin was found in the final multivariate logistic regression model. In addition, bee mortality rate was significantly higher in samples contained Chlorenvinfos (two-sample Wilcoxon rank-sum test; $P=0.026$ ).

\subsubsection{Development of a risk-based model}

The area under the ROC curve (AUC) was estimated for 10 different ROC curves, i.e. with the first, the first two, the first three, until it incorporated the first ten most commonly found residues presented in Table 5. The two ROC curves with close higher AUC were retained for future fitting of the binomial model (Fig. 3). The final model retained and presented in Fig. 4 corresponds to the ROC curve fitted with the higher AUC, i.e. the ROC curve fitted with the three first pesticide residues related to the colony bee mortality (i.e. bromopropylate, chlorfenvinphos and chlorpyrifos-(ethyl)). For this final ROC curve, the AUC $=0.6128$ (Fig. 4). Considering this final ROC curve, the best cut-off related to the prediction of the colony bee mortality corresponds to at least one of these three residues (Fig. 4).

\subsection{Potential interactions of residues}

We looked for the most prevalent pesticide combination in all wax types combined $(N=182)$. The most frequent combination was taufluvalinate together with coumaphos $(N=142)$, tau-fluvalinate together with coumaphos, and propargite $(N=94)$, tau-fluvalinate together with DEET and coumaphos $(N=56)$, coumaphos together with propargite and tau-fluvalinate $(N=48)$, coumaphos together with chlorfenvinphos $(N=44)$. Other relevant combinations with proven synergies we detected were; amitraz together with taufluvalinate $(N=37)$, piperonyl butoxide together with fenpyroximate $(\mathrm{N}=9)$, chlorothalonil together with coumaphos $(\mathrm{N}=1)$, and taufluvalinate $(\mathrm{N}=1)$. 
Table 4

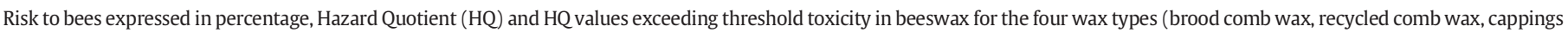
wax and honey comb wax) for two different tau-fluvalinate $\mathrm{LD}_{50}$ values.

\begin{tabular}{|c|c|c|c|c|c|c|}
\hline \multicolumn{2}{|c|}{ Tau-fluvalinate $\mathrm{DL}_{50}\left(\mu \mathrm{g}\right.$ bee $\left.^{-1}\right)$} & \multirow{2}{*}{$\begin{array}{l}\text { HQ value } \\
\text { Mean }\end{array}$} & \multirow{2}{*}{$\frac{\text { Brood comb wax }(\mathrm{N}=89)}{5562}$} & \multirow{2}{*}{$\frac{\text { Recycled wax }(\mathrm{N}=59)}{1901}$} & \multirow{2}{*}{$\frac{\text { Cappings wax }(\mathrm{N}=28)}{54}$} & \multirow{2}{*}{$\frac{\text { Honey comb wax }(\mathrm{N}=6)}{213}$} \\
\hline 12 (Lewis et al.,2016) & $\mathrm{HQ}_{1}$ & & & & & \\
\hline & & SD & 49,395 & 9855 & 116 & 193 \\
\hline & & Median & 27 & 136 & 4 & 169 \\
\hline & & Min & 0 & 0 & 0 & 6 \\
\hline & & Max & 466,249 & 74,208 & 507 & 452 \\
\hline & & $250>$ value $>5000$ & 24 & 26 & 2 & 3 \\
\hline & & Value $>5000$ & 2 & 2 & 0 & 0 \\
\hline & Risk \% & Mean & 0.151 & 0.123 & 0.007 & 0.048 \\
\hline & & SD & 0.010 & 2.399 & 0.011 & 0.044 \\
\hline & & Median & 1.079 & 0.553 & 0.001 & 0.034 \\
\hline & & Min & 0 & 0 & 0 & 0 \\
\hline & & Max & 10.193 & 4.264 & 0.039 & 0.090 \\
\hline \multirow[t]{12}{*}{0.2 (EPA, 2008) } & $\mathrm{HQ}_{2}$ & Mean & 7961 & 4238 & 533 & 2262 \\
\hline & & SD & 49,745 & 11,341 & 744 & 1581 \\
\hline & & Median & 753 & 1330 & 184 & 2466 \\
\hline & & Min & 0 & 0 & 0 & 75 \\
\hline & & Max & 468,324 & 75,476 & 2677 & 4584 \\
\hline & & $250>$ value $>5000$ & 54 & 42 & 11 & 5 \\
\hline & & Value $>5000$ & 10 & 9 & 0 & 0 \\
\hline & Risk \% & Mean & 1.219 & 1.194 & 0.160 & 1.037 \\
\hline & & SD & 2.924 & 2.706 & 0.053 & 1.064 \\
\hline & & Median & 0.283 & 0.507 & 0.240 & 0.771 \\
\hline & & Min & 0 & 0 & 0 & 0 \\
\hline & & Max & 14.376 & 19.958 & 0.871 & 2.213 \\
\hline
\end{tabular}

Legend: $\mathrm{LD}_{50}$, acute median lethal dose; $\mathrm{HQ}_{1}$ and $\mathrm{HQ}_{2}$, Hazard Quotient calculated 2 different tau-fluvalinate $\mathrm{LD}_{50}$ values.

\section{Discussion}

\subsection{Validation of analytical method}

The QuEChERS extraction method followed by LC-MS/MS is well established to assess pesticide residues in beeswax (Herrera López et al., 2016; Niell et al., 2014; Svečnjak et al., 2019). From an analytical point of view, sample preparation should guarantee the representativeness and complete extraction of the residues for a high recovery (Niell et al., 2014). As pesticide residues in beeswax samples are not evenly distributed, beeswax wax was grounded and homogenised using liquid nitrogen. This method allows limits of quantification (LOQs) of $0.01 \mathrm{mg} / \mathrm{kg}$ and limits of detection (LODs) of $0.003 \mathrm{mg} / \mathrm{kg}$ for most residues, these limits were considered as the lowest successfully validated levels, that is, the levels at which acceptable recoveries (70-120\%) were achieved.

Pesticides and veterinary drug residues in beeswax.

The results confirmed our first hypothesis; residues of pesticides applied in agriculture and as veterinary drugs in-hive are ubiquitous contaminants in beeswax. In 2012, Ravoet et al. (2015) already reported the presence of 18 pesticide residues in a restricted area in Flanders with a similar median number of residues per wax sample. Simon-Delso et al.

Table 5

Univariate logistic regression model outcome, pesticides with possible correlation to bee mortality (only pesticides with $P$ value $<0.2$ are presented).

\begin{tabular}{llll}
\hline Pesticides with $P$ value $<0.20$ & Odds ratio & $95 \% \mathrm{CI}$ & $P$ value \\
\hline Bromopropylate & 1.68 & $0.86-3.27$ & 0.124 \\
Chlorfenvinphos & 2.24 & $1.09-4.58$ & $0.028^{*}$ \\
Chlorpyrifos (-ethyl) & 2.38 & $0.88-6.44$ & 0.088 \\
Diclofluanid & 2.43 & $0.62-9.46$ & 0.2 \\
Pendimethalin & 0.21 & $0.02-1.90$ & 0.16 \\
Permethrin & 2.06 & $0.93-4.53$ & 0.072 \\
Piperonylbutoxid & 1.58 & $0.82-3.04$ & 0.175 \\
p.p'-DDT & 4.51 & $0.52-39.4$ & 0.17 \\
Propargite & 1.80 & $0.99-3.25$ & 0.051 \\
Thiacloprid & 0.12 & $0.007-2.34$ & 0.16 \\
\hline
\end{tabular}

Legend: $\mathrm{CI}$, confidence interval; ${ }^{*} P$ value $<0.05$.
(2014) analysed 54 wax samples for 99 different residues, detecting 15 different active ingredients overall. Worldwide, numerous studies (Boi et al., 2016; Calatayud-Vernich et al., 2017; Chauzat and Faucon, 2007; Fulton et al., 2019; Harriet et al., 2017; Lozano et al., 2019; Serra-Bonvehí and Orantes-Bermejo, 2010; Shimshoni et al., 2019; Zawislak et al., 2019) acknowledge that beeswax is a major contamination sink for pesticide residues, thereby constituting hazardous health implications for bees and potentially for humans.

Overall in our study, typical residues of beekeeper-applied veterinary treatments such as tau-fluvalinate (Apistan $\left.{ }^{\circledR}\right)$ and coumaphos (Checkmite ${ }^{\circledR}$ ) had the highest contamination prevalence and concentrations. These products, by design, have low toxicity relative to the dose required for adverse effects. Pesticide residues from agricultural were found with lower prevalence and concentrations, nevertheless, these products have higher toxicity to bees and are known to have synergistic effects with other pesticides, which increase the toxicity of one or more of the compounds (Johnson et al., 2013; Thompson and Wilkins, 2003).

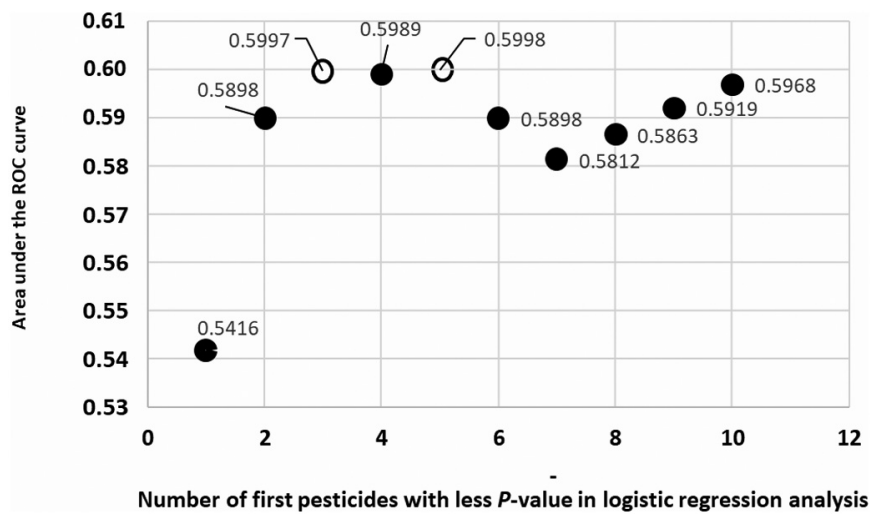

Fig. 3. Area under the curve estimated for each of the ten receiver operating characteristic (ROC) curves tested. Legend: Circle, area under the curve for each of the ten different receiver operating characteristic (ROC) curves tested; black circle, ROC curve not retained; circle with white centre, two best ROC curves retained. 


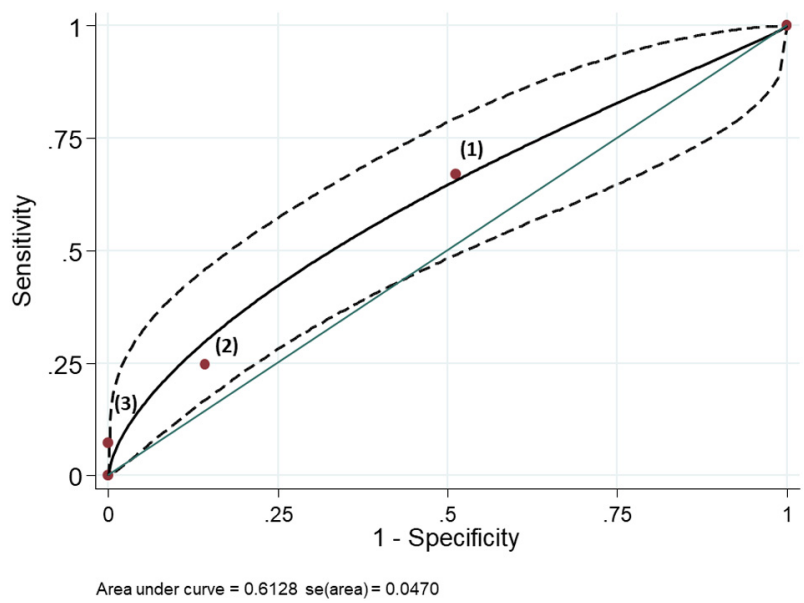

Fig. 4. Best predicted receiver operating characteristic (ROC) curve. Legend: ROC, Receiver Operating Characteristic; solid line, fitted ROC curve (fitting binormal model); dashed lines, $95 \%$ confidence interval of the fitted ROC curve; cut-off ( = number of pesticides in the combination of the three pesticide residues considered) was noted as a number in brackets. The best cut-off corresponds to at least one pesticide residue(s) of the three considered.

Tau-fluvalinate and coumaphos are currently not approved in Belgium but are permitted in at least one of the other Member States of the European Union. Through the "cascade system ${ }^{5}$ " (El Agrebi et al., 2019), they can, therefore, be used in Belgium, under certain conditions and the responsibility of a veterinarian. Their frequent use over the past few years resulted in substantial residue levels in beeswax. These Varroa-treatments are well known and have previously been reported worldwide as prevalent contaminants in honey bee colonies (Bommuraj et al., 2019; Chauzat and Faucon, 2007; Harriet et al., 2017; Herrera López et al., 2016; Johnson et al., 2010; Mullin et al., 2010; Perugini et al., 2018; Van Engelsdorp et al., 2010). The high chemical stability and the low migration rate of these highly lipophilic acaricides drive them to accumulate in wax to concentrations up to the mg $\mathrm{kg}^{-1}$ (Lozano et al., 2019). This phenomenon seems to occur especially with coumaphos, whose concentration levels vary significantly from $0.01 \mathrm{mg} \mathrm{kg}^{-1}$ up to $7.41 \mathrm{mg} \mathrm{kg}^{-1}$, probably due to different application events, but also to its high beeswax persistence (half-life of 115-356 days) (Martel et al., 2007; Zhu et al., 2014) and the extensive recycling of old beeswax into new foundations.

In contrast amitraz (Apivar ${ }^{\circledR}$ ), an approved acaricide that is frequently used in Belgium is rarely detected in beeswax samples, due to its short half-life, requiring its quantification indirectly through its metabolites (Shimshoni et al., 2019). Amitraz is reported to degrade within 1 day in beeswax and within 10 days in honey (Korta et al., 2001). In our study, one very high amitraz detection $\left(16.7 \mathrm{mg} \mathrm{kg}^{-1}\right)$ was registered in a comb wax; probably due to a massive recent application. No other value exceeded $0.54 \mathrm{mg} \mathrm{kg}^{-1}$.

Other acaricides were also found with a high prevalence (28\%) such as bromopropylate (and its metabolite dibromo-benzophenone). This acaricide was used in the early years of Varroa-treatments (e.g. Folbex $V A \circledast$ ), in addition to its agricultural use against other mites. Bromopropylate shows high lipophilic properties $(\log P=5.4)$ and high persistence, therefore its use in agriculture was banned in Europe in 2003 and Belgium in 2007 (Commission Regulation (EC) No 2076/ 2002). Nowadays, its use in beekeeping is no longer approved. The acaricide propargite was detected with a high prevalence (53.3\%) as well. This residue comes from agricultural applications and not from Varroa control. Its accumulation in beeswax came from external contaminants brought back to the hive via foraging. Its use is no longer authorized by the European regulation (EC) 1107/2009.

\footnotetext{
${ }^{5}$ The cascade system was introduced to solve the general problem of availability of veterinary medicinal products for minor species and for minor uses.
}

Agricultural pesticides such as piperonyl butoxide were found with a prevalence of $29.1 \%$, it is a classic P450 inhibitor that has been reported to increase the toxicity of thiacloprid to honey bee (Iwasa et al., 2004) and to affect the bee's ability to detoxify, contributing significantly to honey bee intolerance of pyrethroid insecticides (Johnson et al., 2006). Diethyltoluamide (DEET) an insect repellent, was found with a prevalence of 36.3\%, confirming its presence in Belgian beeswax (Ravoet et al., 2015). DEET has relatively high lipophilic properties ( $\log P=$ 2.1), which could explain its accumulation. Nevertheless, DEET contamination source could not be determined.

We analysed the samples for six neonicotinoids insecticides. Similarly to the study of Simon-Delso et al., (2014), only residues of thiacloprid were detected in 3 wax samples. In the past years, neonicotinoids have been under particular surveillance for their implication in honey bee losses, and their use as seed treatments has been partially restricted in the European Union (European Commission, 2013).

More alarming was the detection of highly toxic to bees and EU banned molecules such as lindane (gamma-HCH) (prevalence of 3.29\%) and dichlorodiphenyltrichloroethane (DDT) including its breakdown product dichlorodiphenyldichloroethylene (prevalence of $0.54 \%$ ). Since 2008, all uses of lindane are banned in the EU. In 2009, lindane and two other $\mathrm{HCH}$-isomers were included in the Stockholm Convention (ECE/EB.AIR/104) on Persistent Organic Pollutants (POPs) to achieve the global elimination of these substances (Vega et al., 2016). DDT's use has also been banned in Europe since 2009 (Regulation (EC) No $1107 / 2009$ ). Our results confirm previous ones showing that pesticides can continue to contaminate the environment long after their ban (Tosi et al., 2018).

\subsection{Pesticide and veterinary drug residues and honey bee mortality}

In the multivariate logistic regression analysis, only chlorfenvinphos appeared to have a significant correlation with bee mortality $(\mathrm{OR}=$ 2.15; 95\% CI: $1.04-4.44 ; P=0.038$ ), in the risk-based model, this compound was also targeted. The Honey bee mortality data used should be interpreted with caution as the underlying factors responsible for bee mortality are generally multi-factorial (Potts et al., 2010).

Chlorfenvinphos use is no longer authorized for agricultural use in the EU (Commission Regulation (EC) No 2076/2002) and is not approved as veterinary treatment for controlling this, the molecule was found in $24.7 \%$ of all wax samples. As no maximum residue level (MRL) was defined for the substance, a default value of $0.01 \mathrm{mg} \mathrm{kg}^{-1}$ is applied as MRL for honey following Reg. (EC) No 396/2005. The mean concentration in beeswax of the positive samples to chlorfenvinphos (all wax types together) is $0.033 \mathrm{mg} \mathrm{kg}^{-1}$ (min-max: $0.01-0.15 \mathrm{mg}$ $\mathrm{kg}^{-1}$ ), thus exceeding the MRL set for the honey of $0.01 \mathrm{mg} \mathrm{kg}{ }^{-1}$. Chlorfenvinphos presence has already been reported in a previous Belgian survey, with $50 \%$ occurrence $(N=10)$ and a concentration fluctuating between 0.008 and $0.015 \mathrm{mg} \mathrm{kg}^{-1}$ (Ravoet et al., 2015) as well as in a German study in $8.6 \%$ of the analysed samples $(N=288)$, with concentrations ranging from 0.001 to $6.4 \mathrm{mg} \mathrm{kg}^{-1}$ (Shimshoni et al., 2019). In Italy, $34.5 \%$ of the analysed wax samples $(N=178)$ were positive to chlorfenvinphos with concentrations reported of 0.01 to $0.63 \mathrm{mg}$ $\mathrm{kg}^{-1}$ (Perugini et al., 2018). Pollen was as well continuously contaminated over months and years (Tosi et al., 2018). In Spain, 88.5\% of the samples were found positive for chlorfenvinphos, with concentrations up to $10.64 \mathrm{mg} \mathrm{kg}^{-1}$ during a survey between 1996 and 2006 (Orantes-Bermejo et al., 2010). In another Spanish study, differentiating wax types, Calatayud-Vernich et al. (2019) reported a 100\% prevalence and concentrations ranging from 0.21 to $0.79 \mathrm{mg} \mathrm{kg}^{-1}$ in old comb wax, $33.3 \%$ prevalence and concentrations ranging from 0.005 to $0.05 \mathrm{mg} \mathrm{kg}^{-1}$ in cappings wax.

Studies on the effects of chlorfenvinphos on honey bee larvae health are not yet available. However, like coumaphos, it is an organophosphorus insecticide, whose adverse effects on adult worker bees have been studied at different levels (Fell and Tignor, 2001; Haarmann et al., 2002; 
Pettis et al., 2004). The origin of chlorfenvinphos in Belgian waxes is uncertain. Chlorfenvinphos illegal use as acaricide has been suspected in Spain, Portugal, France, and Italy (Orantes-Bermejo et al., 2010), where unauthorized chemicals are used as an alternative to the limited efficacy of some authorized treatments. The residues may also have been taken up by honey bees during the collection of nectar and/or pollen in the environment around the hive when the pesticide was illegally applied on flowering crops (Lozano et al., 2019). Chlorfenvinphos could also originate from river pollution, the substance has been identified among 45 other as a priority substances to be monitored in the European Union (Directive 2013/39/EU) (Pistocchi et al., 2019). Another possible route of wax contamination is the use of legally traded wax from non-EU countries. Chlorfenvinphos concentrations in Belgian beeswax appear to be low and therefore does not seem to be the result of illegal use in-hive as veterinary treatment.

\subsection{Wax Hazard Quotient and toxicity to honey bees}

Overall, in the first scenario (tau-fluvalinate $\mathrm{DL}_{50}=12 \mu \mathrm{g} \mathrm{bee}^{-1}$ ), the majority of the analysed samples $(68 \%)$ had a low HQ value $(<250)$ and should not represent a danger for honey bees, nevertheless, $30.2 \%$ have significant $\mathrm{HQ}$

The mean HQ value for brood comb $(N=89)$ showed the highest toxicity to bees ( $\mu=5562 ; \sigma=49,395$ : $\min -\max : 0-466,249)$, this value is due to one sample with an extremely high HQ value $(466,249)$ elevating the HQ mean significantly from 326.7 to 5562 . The sample contaminated with a high concentration of cypermethrin $\left(9.3 \mathrm{mg} \mathrm{kg}^{-1}\right)$ was recorded in the province of Luxembourg, where agricultural land is essentially devoted to dairy and, above all, meat cattle farming. Cypermethrin is used massively in livestock worldwide for topical administration, either as concentrates for dipping or spraying or in ready-to-use products such as pour-on, dressings, ear-tags. In recycled wax $(N=59)(\mu=1901 ; \sigma=$ 9855; min-max: 0-74,208) mean HQ value is significantly high $(250<\mathrm{HQ}<5000)$ but again, was due to 2 samples with extremely elevated toxicity values $(17,536$ and 74,208$)$. These values elevated the mean HQ value from 358.2 to 1901 . Two contamination ( $\mathrm{HQ}=74,208$ and 5242) were located in the province of Limburg, in a region devoted to horticulture, the other in East Flanders $(\mathrm{HQ}=17,536)$. The contaminations in Limburg are due to permethrin $\left(0.31 \mathrm{mg} \mathrm{kg}^{-1}\right)$ and chlorpyrifos (ethyl) ( $4.38 \mathrm{mg} \mathrm{kg}^{-1}$ ) both used over a long period respectively to control Lepidoptera and Coleoptera in ornamental, fruit and vegetable crops and a wide range of foliar pests. In East Flanders (cattle farming), the contamination was due to the presence of deltamethrin $\left(0.026 \mathrm{mg} \mathrm{kg}^{-1}\right)$ and lindane $\left(0.021 \mathrm{mg} \mathrm{kg}^{-1}\right)$. Deltamethrin is a pyrethroid insecticide used to eradicate external parasites on animal farms, lindane an obsolete topical substance that was used to treat parasites. Honey comb $(N=6)(\mu=$ 213; $\sigma=193$ : min-max: 6-452), had three samples with significant toxicity. The limited number of honey comb wax samples does not allow us to draw clear conclusions about this wax type.

Cappings wax $(N=28)$ had the lowest mean $(\mu=53 ; \sigma=114$; min-max: 0-507), this maximum value (507) is due to permethrin contamination in a single sample. Two samples were found with significant toxicity $(250<\mathrm{HQ}<5000)$. Cappings wax and honey comb wax toxicity can be considered as low or non-toxic to bees compared to recycled and brood comb wax.

The results of our study are very much in line with the findings of Calatayud-Vernich et al., 2017; where pyrethroids together with organophosphate chlorpyrifos were the main contributors to the HQ scores. This is due to their great toxicity through contact for honey bees and/or significant concentrations in the samples. Furthermore, cappings wax were also substantially less contaminated than foundations (made out of recycled wax) (CalatayudVernich et al., 2017; Harriet et al., 2017) and old combs beeswax.

With the second toxicity scenario (tau-fluvalinate $D L_{50}=0.2 \mu \mathrm{g}$ bee ${ }^{-1}$ ), the HQ levels near alarming levels, and the number of samples exceeding threshold values increases. A revision is needed to clarify Tau-fluvalinate $D L_{50}$ value.

The HQ model used in this study is simplistic as it considers toxic effects as cumulative and additive but does not take into account any synergistic or antagonistic effects, as these are not yet well documented and thus not yet integrated into the used equation. Better models for estimation of potential adverse effects of residue cocktails with greater reliability than those already existing are needed to assess more properly the potential risks of residues.

Cumulative risk by contact exposure to honey bee larvae.

The highest risk was posed by brood comb wax where $15 \%$ of larvae were exposed to pesticide doses higher than the lethal dose, followed by the recycled comb, and honey comb wax. Our results point out that cappings wax was substantially less contaminated than the 3 other wax types and presented a very limited risk $(0.7 \%)$. In the scenario were tau-fluvalinate $\mathrm{DL}_{50}=0.2 \mu \mathrm{g}$ bee $^{-1}$, the cumulative by contact exposure risk increased considerably to exceed $100 \%$ except for cappings wax (16\%) but is still high. However, it may not be appropriate to assess risk by acute $\mathrm{DL}_{50}$ values for adult honey bees when it is the larvae that develop in wax for a specific time, hence the cumulative risk value estimated using the current calculation represents an inaccurate scenario, but to date, the necessary toxicity values for larvae is not sufficiently documented. Other studies already estimated contact exposure risk to worker bees or bee larvae of single pesticides (Harriet et al., 2017; Sanchez-Bayo and Goka, 2014). Using a slightly different equation, Harriet et al., 2017, found Chlorpyrifos-ethyl (198\%) and coumaphos (21\%) to have the highest risk to bee larvae.

\subsection{Potential synergies and interactions of residues}

With up to 12 different residues detected in a single wax sample, it is very difficult to elucidate the potential interactions of products. The risk assessments may thus underestimate the true risk to bees, as the more residues in a given sample, the greater potential for unexpected synergistic interactions. The most prevalent combinations included acaricides for Varroa treatments as they are directly applied in the hive. Pesticide residues synergies have scarcely been evaluated, nevertheless, the current pesticide combinations would probably damage colony health, because synergistic effects have been identified for combinations such as piperonyl butoxide that seems to increases the toxicity of fenpyroximate, while amitraz seems to increase the toxicity of taufluvalinate (Johnson et al., 2013).

\section{Conclusion}

Bees are at risk from many stress factors, which occur individually but most commonly in combinations, affecting bee health and mortality. Pesticides are one of the factors impacting colony health. Our study highlights the ubiquitous presence of pesticides in all wax types, besides veterinary drug residues have the highest concentration and prevalence but the lowest toxicity compared to agricultural pesticides that have a lower prevalence but higher toxicity to bees and can have synergistic effects with other pesticides. Significantly lower residue diversity and concentrations were found in cappings wax compared to the other three types. Brood comb wax exhibited the highest rates of contamination. In light of these results, beekeepers should replace brood comb wax more frequently than recommended (1/4 to $1 / 3$ of than old brood frames (ITSAP, 2017)) rather than recycling them back into the wax stream, where they will continue to potentially impact colony health. We highly recommend the use of greater amounts of cappings wax in the manufacturing process of foundation, the substrate beekeepers purchase to aid their bees in building comb, as well as using organic wax sources to gradually decrease residues in the colony matrix. Furthermore, the marketing and the recommendation regarding the use of plant protection products and as well as veterinary 
treatments should take into account that compounds with highly lipophilic properties accumulate in wax. Given the large number of residues found in beeswax and the amount of potential synergistic effects among the different residues detected, we recommend testing commonly found combinations in field experiments to determine the potential synergetic effects on colony health. The use of alternative veterinary substances (e.g. acids) should be encouraged. An educational campaign for users of pesticides or veterinary drugs is needed to increase awareness and good practices. The use of the BeeToxWax tool designed to estimate the risk associated with contaminated beeswax is recommended when pesticide analyses are available (Appendix 2). It is crucial to introduce maximum residue limits for beeswax trade, taking into account residue toxicity for bees and, ideally, for their larvae. Furthermore, EPA and PPDB toxicity values for tau-fluvalinate should be scientifically re-examined in depth.

\section{Abbreviations used}

$\begin{array}{ll}\text { ABP } & \text { animal by-products } \\ \text { AUC } & \text { Area under the curve } \\ \text { DEET } & \text { N,N-Diéthyl-3-méthylbenzamide } \\ \text { EFSA } & \text { European Food Safety Authority } \\ \text { EMA } & \text { European Medicines Agency } \\ \text { EPA } & \text { Unites States Environmental protection Agency } \\ \text { FASFC } & \text { Federal Agency for the Safety of the Food Chain } \\ \text { HQ } & \text { Hazard Quotient }\end{array}$

\section{LC/MS-MS}

liquid chromatography/tandem mass spectroscopy

GC/MS-MS

gas chromatography/tandem mass spectroscopy

GC-MSD gas chromatography-mass selective detector

$\mathrm{LD}_{50} \quad$ Acute median lethal dose after $48 \mathrm{~h}$ of exposition $=$ is a statistically derived single dose of a substance that can cause death in $50 \%$ of animals when administered by the oral route/by contact. The $\mathrm{LD}_{50}$ value is expressed in $\mu \mathrm{g}$ of test substance per bee. For pesticides, the test substance may be either an active ingredient (a.i.) or a formulated product containing one or more than one active ingredient (OECD, 2017)

LOD Limit of detection

LOQ Limit of quantification

MRL Maximum Residue Limit

PPDB Pesticides properties DataBase

QuEChERS Quick Easy Cheap Effective Rugged Safe

ROC Receiver operating characteristic

VSDB Veterinary Substances DataBase

\section{CRediT authorship contribution statement}

Noëmie El Agrebi: Conceptualization, Methodology, Software, Data curation, Writing - original draft, Visualization, Investigation. Kirsten Traynor: Writing - review \& editing. Olivier Wilmart: Writing - review \& editing, Data curation, Validation. Simone Tosi: Writing - review \& editing. Laurent Leinartz: Software, Visualization. Ellen Danneels: Writing - review \& editing. Dirk C. de Graaf: Writing - review \& editing. Claude Saegerman: Conceptualization, Methodology, Software, Data curation, Visualization, Investigation, Writing - review \& editing.

\section{Declaration of competing interest}

The authors declare that they have no known competing financial interests or personal relationships that could have appeared to influence the work reported in this paper.

\section{Acknowledgments}

This study was supported by the Belgian Federal Public Service of Health, Food Chain Safety and Environment as part of the RF 15/6300 Bee Best Check research project as well by the SPW ARNE (Service public de Wallonie. Agriculture, Ressources naturelles et Environnement) (Grant RW D32-0286, Bee Tox Check) and the University of Liège (Grant FSR-F-VT-16/16, Bee Tox Check). This work would not have been accomplished without the help of the Belgian beekeepers, beekeeping unions that we thank for their time, trust and for providing us wax samples.

\section{Appendix A. Supplementary data}

Supplementary data to this article can be found online at https://doi. org/10.1016/j.scitotenv.2020.141036.

\section{References}

Aichholz, R., Lorbeer, E., 1999. Investigation of combwax of honeybees with hightemperature gas chromatography and high-temperature gas chromatographychemical ionization mass spectrometry. I. High-temperature gas chromatography. J. Chromatogr. A 855, 601-615. https://doi.org/10.1016/S0021-9673(99) 00725-6.

Balayiannis, G., Balayiannis, P., 2008. Bee honey as an environmental bioindicator of pesticides' occurrence in six agricultural areas of Greece. Arch. Environ. Contam. Toxicol. 55, 462-470. https://doi.org/10.1007/s00244-007-9126-X.

Berthoud, H., Imdorf, A., Haueter, M., Radloff, S., Neumann, P., 2010. Virus infections and winter losses of honey bee colonies (Apis mellifera). J. Apic. Res. 49, 60-65. https:// doi.org/10.3896/IBRA.1.49.1.08.

Bogdanov, S., 2006. Contaminants of bee products. Apidologie 37, 1-18.

Bogdanov, S., 2016. Beeswax: Production, Properties, Composition, Control.

Bogdanov, S., Kilchenmann, V., Imdorf, A., 1998. Acaricide residues in some bee products. J. Apic. Res. 37, 57-67. https://doi.org/10.1080/00218839.1998.11100956.

Boi, M., Serra, G., Colombo, R., Lodesani, M., Massi, S., Costa, C., 2016. A 10 year survey of acaricide residues in beeswax analysed in Italy. Pest Manag. Sci. 72, 1366-1372. https://doi.org/10.1002/ps.4161.

Bommuraj, V., Chen, Y., Klein, H., Sperling, R., Barel, S., Shimshoni, J.A., 2019. Pesticide and trace element residues in honey and beeswax combs from Israel in association with human risk assessment and honey adulteration. Food Chem. 299, 125123. https:// doi.org/10.1016/J.FOODCHEM.2019.125123.

Calatayud-Vernich, P., Calatayud, F., Simó, E., Picó, Y., 2017. Occurrence of pesticide residues in Spanish beeswax. Sci. Total Environ. 605-606, 745-754. https://doi.org/ 10.1016/J.SCITOTENV.2017.06.174.

Calatayud-Vernich, P., Calatayud, F., Simó, E., Pascual Aguilar, J.A., Picó, Y., 2019. A twoyear monitoring of pesticide hazard in-hive: high honey bee mortality rates during insecticide poisoning episodes in apiaries located near agricultural settings. Chemosphere 232, 471-480. https://doi.org/10.1016/J.CHEMOSPHERE.2019.05.170.

Carnesecchi, E., Svendsen, C., Lasagni, S., Grech, A., Quignot, N., Amzal, B., Toma, C., Tosi, S. Rortais, A., Cortinas-Abrahantes, J., Capri, E., Kramer, N., Benfenati, E., Spurgeon, D., Guillot, G., Dorne, J.L.C.M., 2019. Investigating combined toxicity of binary mixtures in bees: meta-analysis of laboratory tests, modelling, mechanistic basis and implications for risk assessment. Environ. Int. 133, 105256. https://doi.org/10.1016/j. envint.2019.105256.

Chauzat, M.-P., Faucon, J.-P., 2007. Pesticide residues in beeswax samples collected from honey bee colonies (Apis mellifera L.) in France. Pest Manag. Sci. 63, 1100-1106. https://doi.org/10.1002/ps.1451.

Chauzat, M.-P., Martel, A.-C., Cougoule, N., Porta, P., Lachaize, J., Zeggane, S., Aubert, M., Carpentier, P., Faucon, J.-P., 2011. An assessment of honeybee colony matrices, Apis mellifera (Hymenoptera: Apidae) to monitor pesticide presence in continental France. Environ. Toxicol. Chem. 30, 103-111. https:// doi.org/10.1002/etc.361.

Clermont, A., Eickermann, M., Kraus, F., Georges, C., Hoffmann, L., Beyer, M., 2014. A survey on some factors potentially affecting losses of managed honey bee colonies in Luxembourg over the winters 2010/2011 and 2011/2012. J. Apic. Res. 53, 43-56. https://doi.org/10.3896/IBRA.1.53.1.04

Dainat, B., Evans, J.D., Chen, Y.P., Gauthier, L., Neumann, P., 2012. Predictive markers of honey bee colony collapse. PLoS One 7, e32151. https://doi.org/10.1371/journal. pone.0032151.

Desneux, N., Decourtye, A., Delpuech, J.-M., 2007. The sublethal effects of pesticides on beneficial arthropods. Annu. Rev. Entomol. 52, 81-106. https://doi.org/10.1146/ annurev.ento.52.110405.091440.

EFSA, 2012. Scientific opinion on the science behind the development of a risk assessment of plant protection products on bees (Apis mellifera, Bombus spp. and solitary bees). EFSA J. 10, 2668. https://doi.org/10.2903/j.efsa.2012.2668.

El Agrebi, N., Wilmart, O., Urbain, B., Danneels, E.L., de Graaf, D.C., Saegerman, C., 2019 Belgian case study on flumethrin residues in beeswax: possible impact on honeybee and prediction of the maximum daily intake for consumers. Sci. Total Environ. 687, 712-719. https://doi.org/10.1016/J.SCITOTENV.2019.05.493.

EPA, 2005. Reregistration eligibility decision (RED) for Tau-fluvalinate. United States Environmental Protection Agency, Office of Pesticide Programs, Washington, D.C, USA 
Document $\mathrm{N}^{\circ}$ OPP-2005-0230-0002. EPA 78-pages. https://archive.epa.gov/pesticides/reregistration/web/pdf/taufluvalinate_red.pdf.

European Commission, 2013. Conclusion on the peer review of the pesticide risk assessment for bees for the active substance thiamethoxam. EFSA J. 11, 3067. https://doi. org/10.2903/j.efsa.2013.3067.

Fell, R.D., Tignor, K., 2001. Miticide effects on the reproductive physiology of queens and drones. Am. Bee J. 141, 888-889.

Fulton, C.A., Huff Hartz, K.E., Fell, R.D., Brewster, C.C., Reeve, J.D., Lydy, M.J., 2019. An assessment of pesticide exposures and land use of honey bees in Virginia. Chemosphere 222, 489-493. https://doi.org/10.1016/J.CHEMOSPHERE.2019.01.156.

Goulson, D., Nicholls, E., Botías, C., Rotheray, E.L., 2015. Bee declines driven by combined stress from parasites, pesticides, and lack of flowers. Science (80-.) 347.

Haarmann, T., Spivak, M., Weaver, D., Weaver, B., Glenn, T., 2002. Effects of fluvalinate and coumaphos on queen honey bees (Hymenoptera: Apidae) in two commercial queen rearing operations. J. Econ. Entomol. 95, 28-35. https://doi.org/10.1603/0022-0493 95.1.28.

Harriet, J., Camp, J.P., Grajales, M., Lh Eritier, C., Omez Pajuelo, A.G., Mendoza-Spina, Y., Carrasco-Letelier, L., 2017. Agricultural pesticides and veterinary substances in Uruguayan beeswax. Chemosphere 177, 77-83. https://doi.org/10.1016/j. chemosphere.2017.02.131.

Haschek, W.M., Rousseaux, C.G., Wallig, M.A., 2013. Haschek and Rousseaux's Handbook of Toxicologic Pathology. Academic Press.

Herrera López, S., Lozano, A., Sosa, A., Hernando, M.D., Fernández-Alba, A.R., 2016 Screening of pesticide residues in honeybee wax comb by LC-ESI-MS/MS. pilot study. Chemosphere 163, 44-53. https://doi.org/10.1016/J. CHEMOSPHERE.2016.07.008.

ITSAP, 2017. Guide des bonnes pratiques apicoles.

Iwasa, T., Motoyama, N., Ambrose, J.T., Roe, R.M., 2004. Mechanism for the differential toxicity of neonicotinoid insecticides in the honey bee, Apis mellifera. Crop Prot. 23 371-378. https://doi.org/10.1016/j.cropro.2003.08.018.

Johnson, R.M., Wen, Z., Schuler, M.A., Berenbaum, M.R., 2006. Mediation of pyrethroid insecticide toxicity to honey bees (Hymenoptera: Apidae) by cytochrome P450 monooxygenases. Berenbaum Source J. Econ. Entomol. J. Econ. Entomol 99, 1046-1050. https://doi.org/10.1603/0022-0493-99.4.1046.

Johnson, R.M., Ellis, M.D., Mullin, C.A., Frazier, M., 2010. Pesticides and honey bee toxicity - USA. Apidologie 41, 312-331. https://doi.org/10.1051/apido/2010018.

Johnson, R.M., Dahlgren, L., Siegfried, D., Ellis, M.D., Wang, X., 2013. Acaricide, fungicide and drug interactions in honey bees (Apis mellifera). PLoS One 8, e54092. https:// doi.org/10.1371/journal.pone.0054092.

Korta, E., Bakkali, A., Berrueta, L.A., Gallo, B., Vicente, F., Kilchenmann, V., Bogdanov, S. 2001. Study of acaricide stability in honey. Characterization of amitraz degradation products in honey and beeswax. J. Agric. Food Chem. 49, 5835-5842. https://doi. org/10.1021/jf010787s

Le Conte, Y., Ellis, M., Ritter, W., 2010. Varroa mites and honey bee health: can Varroa explain part of the colony losses? Apidologie 41, 353-363. https://doi.org/10.1051/ apido/2010017

Lewis, K.A., Tzilivakis, J., Warner, D.J., Green, A., 2016. An international database for pesticide risk assessments and management. Hum. Ecol. Risk. Assess. 22, 1050-1064. https://doi.org/10.1080/10807039.2015.1133242.

Lozano, A., Hernando, M.D., Uclés, S., Hakme, E., Fernández-Alba, A.R., 2019. Identification and measurement of veterinary drug residues in beehive products. Food Chem. 274 61-70. https://doi.org/10.1016/J.FOODCHEM.2018.08.055.

Martel, A.-C., Zeggane, S., Eres, C., Drajnudel, P., Faucon, J.-P., Aubert, M., 2007. Acaricide Residues in Honey and Wax After Treatment of Honey Bee Colonies With Apivar or Asuntol50.

Mitchell, E.A.D., Mulhauser, B., Mulot, M., Mutabazi, A., Glauser, G., Aebi, A., 2017. A world wide survey of neonicotinoids in honey. Science (80-.) 80, 109-111.

Morgenthaler, O., 1968. Les maladies infectieuses des ouvrières. In: Chauvin, R. (Ed.) Traité de Biologie de l'Abeille. Paris, p. 327.

Mullin, C.A., Frazier, M., Frazier, J.L., Ashcraft, S., Simonds, R., vanEngelsdorp, D., Pettis, J.S., 2010. High levels of miticides and agrochemicals in North American apiaries: implications for honey bee health. PLoS One 5, e9754. https://doi.org/10.1371/journal. pone.0009754.

Murcia Morales, M., Gómez Ramos, M.J., Parrilla Vázquez, P., Díaz Galiano, F.J., García Valverde, M., Gámiz López, V., Manuel Flores, J., Fernández-Alba, A.R., 2020. Distribution of chemical residues in the beehive compartments and their transfer to the honeybee brood. Sci. Total Environ. 710, 136288. https://doi.org/10.1016/j. scitotenv.2019.136288.

Niell, S., Cesio, V., Hepperle, J., Doerk, D., Kirsch, L., Kolberg, D., Scherbaum, E., Anastassiades, M., Heinzen, H., 2014. QuEChERS-based method for the multiresidue analysis of pesticides in beeswax by LC-MS/MS and GCxGC-TOF. J. Agric. Food Chem. 62, 3675-3683. https://doi.org/10.1021/jf405771t.

OECD, 2017. Guideline 245 for the testing of chemicals. Honey bee (Apis mellifera L.), chronic oral toxicity test (10-day feeding). OECD/OCDE, OECD Guidelines for the Testing of Chemicals, Section 2. OECD Publishing https://doi.org/10.1787/ 9789264284081-en.

Orantes-Bermejo, F.J., Pajuelo, A.G., Megías, M.M., Torres Fernández-Píñar, C., 2010. Pesticide residues in beeswax and beebread samples collected from honey bee colonies (Apis mellifera L.) in Spain. Possible implications for bee losses. J. Apic. Res. 48 243-250. https://doi.org/10.3896/IBRA.1.49.3.03.

Perugini, M., Tulini, S.M.R., Zezza, D., Fenucci, S., Conte, A., Amorena, M., 2018. Occurrence of agrochemical residues in beeswax samples collected in Italy during 2013-2015. Sci. Total Environ. 625, 470-476. https://doi.org/10.1016/J. SCITOTENV.2017.12.321

Pettis, J.S., Collins, A.M., Wilbanks, R., Feldlaufer, M.F., 2004. Effects of coumaphos on queen rearing in the honey bee, Apis mellifera. Apidologie 35, 605-610.
Pistocchi, A., Dorati, C., Aloe, A., Ginebreda, A., Marcé, R., 2019. River pollution by priority chemical substances under the Water Framework Directive: a provisional panEuropean assessment. Sci. Total Environ. 662, 434-445. https://doi.org/10.1016/j. scitotenv.2018.12.354

Potts, S.G., Biesmeijer, J.C., Kremen, C., Neumann, P., Schweiger, O., Kunin, W.E., 2010. Global pollinator declines: trends, impacts and drivers. Trends Ecol. Evol. 25, 345-353. https://doi.org/10.1016/j.tree.2010.01.007.

Ravoet, J., Reybroeck, W., de Graaf, D.C., 2015. Pesticides for apicultural and/or agricultural application found in Belgian honey bee wax combs. Bull. Environ. Contam. Toxicol. 94, 543-548. https://doi.org/10.1007/s00128-015-1511-y.

Rortais, A., Arnold, G., Halm, M.-P., Touffet-Briens, F., 2005. Modes of honeybees exposure to systemic insecticides: estimated amounts of contaminated pollen and nectar consumed by different categories of bees. Apidologie 36, 71-83. https://doi.org/10.1051/ apido:2004071.

Sanchez-Bayo, F., Goka, K., 2014. Pesticide residues and bees - a risk assessment. PLoS One 9. https://doi.org/10.1371/journal.pone.0094482.

Scientific Committee of the FASFC, 2018. Advice 18-2018 of the Scientific Committee of the FASFC Regarding the Risk to Bee Health of Contaminated and Adulterated Beeswax.

Serra-Bonvehí, J., Orantes-Bermejo, J., 2010. Acaricides and their residues in Spanish commercial beeswax. Pest Manag. Sci. 66, 1230-1235. https://doi.org/ 10.1002/ps.1999.

Shimshoni, J.A., Sperling, R., Massarwa, M., Chen, Y., Bommuraj, V., Borisover, M., Barel, S., 2019. Pesticide distribution and depletion kinetic determination in honey and beeswax: model for pesticide occurrence and distribution in beehive products. PLoS One 14, e0212631. https://doi.org/10.1371/journal. pone.0212631.

Simon-Delso, N., San Martin, G., Bruneau, E., Minsart, L.-A., Mouret, C., Hautier, L., 2014. Honeybee colony disorder in crop areas: the role of pesticides and viruses. PLoS ONE 9 (7), e103073. https://doi.org/10.1371/journal.pone.0103073.

Stoner, K.A., Eitzer, B.D., Pacini, E., Roe, R., Lambin, M., 2013. Using a Hazard Quotient to evaluate pesticide residues detected in pollen trapped from honey bees (Apis mellifera) in Connecticut. PLoS One 8, 1-10. https://doi.org/10.1371/journal. pone.0077550.

Suchail, S., Guez, D., Belzunces, L.P., 2001. Discrepancy between acute and chronic toxicity induced by imidacloprid and its metabolites in Apis mellifera. Environ. Toxicol. Chem. 20, 2482. https://doi.org/10.1897/1551-5028(2001)020<2482: dbaact $>2.0 . \mathrm{co} ; 2$

Svečnjak, L., Chesson, L.A., Gallina, A., Maia, M., Martinello, M., Mutinelli, F., Muz, M.N., Nunes, F.M., Saucy, F., Tipple, B.J., Wallner, K., Waś, E., Waters, T.A., 2019. Standard methods for Apis mellifera beeswax research. J. Apic. Res. 58 (2), 1-108. https://doi. org/10.1080/00218839.2019.1571556.

Thompson, H., Wilkins, S., 2003. Assessment of the synergy and repellency of pyrethroid/ fungicide mixtures. Bull. Insectology 56, 131-134

Tomé, H.V.V., Schmehl, D.R., Wedde, A.E., Godoy, R.S.M., Ravaiano, S.V., Guedes, R.N.C., Martins, G.F., Ellis, J.D., 2020. Frequently encountered pesticides can cause multiple disorders in developing worker honey bees. Environ. Pollut. 256. https://doi.org/ 10.1016/j.envpol.2019.113420.

Tosi, S., Costa, C., Vesco, U., Quaglia, G., Guido, G., 2018. A 3-year survey of Italian honey bee-collected pollen reveals widespread contamination by agricultural pesticides. Sci. Total Environ. 615, 208-218. https://doi.org/10.1016/J. SCITOTENV.2017.09.226

Traynor, K.S., Pettis, J.S., Tarpy, D.R., Mullin, C.A., Frazier, J.L., Frazier, M., vanEngelsdorp, D., 2016. In-hive pesticide exposome: assessing risks to migratory honey bees from inhive pesticide contamination in the Eastern United States. Sci. Rep. 6, 33207. https://doi.org/10.1038/srep33207.

Tsvetkov, N., Samson-Robert, O., Sood, K., Patel, H.S., Malena, D.A., Gajiwala, P.H., Maciukiewicz, P., Fournier, V., Zayed, A., 2017. Chronic exposure to neonicotinoids reduces honey bee health near corn crops. Science (80-.) 356, 1395-1397. https://doi. org $/ 10.1126 /$ science.aam 7470

Tulloch, A.P., 1980. Beeswax-composition and analysis. Bee World 61, 47-62. https://doi. org/10.1080/0005772X.1980.11097776.

Van Engelsdorp, D., Hayes, J., Underwood, R.M., Pettis, J., 2008. A survey of honey bee colony losses in the U.S., fall 2007 to spring 2008. PLoS One 3, e4071. https://doi.org/ 10.1371/journal.pone.0004071.

Van Engelsdorp, D., Mullin, C., Frazier, M., Frazier, J., Cox-Foster, D., Speybroeck, N., Evans, J.D., Chen, Y., Pettis, J.S., Nguyen, B.K., Haubruge, E., Tarpy, D.R., Saegerman, C., 2010. Weighing risk factors associated with bee colony collapse disorder by classification and regression tree analysis. J. Econ. Entomol. 103, 1517-1523. https://doi.org/ 10.1603/EC09429.

Vega, M., Romano, D., Uotila, E., 2016. Lindane (Persistent Organic Pollutant) in the EU.

Wallner, K., 1999. Varroacides and their residues in bee products. Apidologie 30, 235-248.

Washington State Department of Agriculture, 2010. Pollinator Protection Requirements for Section 18 Emergency Exemptions and Section 24(c) Special Local Need Registration in Washington State.

Woodcock, B.A., Bullock, J.M., Shore, R.F., Heard, M.S., Pereira, M.G., Redhead, J., Ridding, L., Dean, H., Sleep, D., Henrys, P., Peyton, J., Hulmes, S., Hulmes, L., Sárospataki, M., Saure, C., Edwards, M., Genersch, E., Knäbe, S., Pywell, R.F., 2017. Country-specific effects of neonicotinoid pesticides on honey bees and wild bees. Science (80-.) 356 , 1393-1395. https://doi.org/10.1126/science.aaa1190.

Wu, J.Y., Anelli, C.M., Sheppard, W.S., 2011. Sub-lethal effects of pesticide residues in brood comb on worker honey bee (Apis mellifera) development and longevity. PLoS One 6, e14720. https://doi.org/10.1371/journal.pone.0014720.

Yáñez, K.P., Bernal, J.L., Nozal, M.J., Martín, M.T., Bernal, J., 2013. Determination of seven neonicotinoid insecticides in beeswax by liquid chromatography coupled to 
electrospray-mass spectrometry using a fused-core column. J. Chromatogr. A 1285 110-117. https://doi.org/10.1016/J.CHROMA.2013.02.032.

Yao, J., Zhu, Y.C., Adamczyk, J., Luttrell, R., 2018. Influences of acephate and mixtures with other commonly used pesticides on honey bee (Apis mellifera) survival and detoxification enzyme activities. Comp. Biochem. Physiol. Part C Toxicol. Pharmacol. 209, 9-17. https://doi.org/10.1016/J.CBPC.2018.03.005.

Zawislak, J., Adamczyk, J., Johnson, D.R., Lorenz, G., Black, J., Hornsby, Q., Stewart, S.D., Joshi, N., 2019. Comprehensive survey of area-wide agricultural pesticide use in southern United States row crops and potential impact on honey bee colonies. Insects 10. https://doi.org/10.3390/insects10090280.

Zhu, W., Schmehl, D.R., Mullin, C.A., Frazier, J.L., 2014. Four common pesticides, their mixtures and a formulation solvent in the hive environment have high oral toxicity to honey bee larvae. PLoS One 9, e77547. https://doi.org/10.1371/journal. pone.0077547. 